\title{
The IL-10 homologue encoded by cyprinid herpesvirus 3 is essential neither for viral replication in vitro nor for virulence in vivo
}

\author{
Ping Ouyang ${ }^{1}$, Krzysztof Rakus ${ }^{1}$, Maxime Boutier ${ }^{1}$, Anca Reschner ${ }^{1}$, Baptiste Leroy ${ }^{2}$, Maygane Ronsmans ${ }^{1}$, \\ Guillaume Fournier', Sophie Scohy ${ }^{3}$, Bérénice Costes ${ }^{4}$, Ruddy Wattiez ${ }^{2}$ and Alain Vanderplasschen ${ }^{1 *}$
}

\begin{abstract}
Cyprinid herpesvirus 3 (CyHV-3), a member of the family Alloherpesviridae, is the causative agent of a lethal disease in common and koi carp. CyHV-3 ORF134 encodes an interleukin-10 (IL-10) homologue. The present study was devoted to this ORF. Transcriptomic analyses revealed that ORF134 is expressed as a spliced gene belonging to the early-late class. Proteomic analyses of CyHV-3 infected cell supernatant demonstrated that the ORF134 expression product is one of the most abundant proteins of the CyHV-3 secretome. To investigate the role of ORF134 in viral replication in vitro and in virulence in vivo, a deleted strain and a derived revertant strain were produced using BAC cloning technologies. The recombinant ORF134 deleted strain replicated in vitro comparably to the parental and the revertant strains. Infection of fish by immersion in water containing the virus induced comparable CyHV-3 disease for the three virus genotypes tested (wild type, deleted and revertant). Quantification of viral DNA by real time TaqMan PCR (in the gills and the kidney) and analysis of carp cytokine expression (in the spleen) by RT-qPCR at different times post-infection did not revealed any significant difference between the groups of fish infected with the three virus genotypes. Similarly, histological examination of the gills and the kidney of infected fish revealed no significant differences between fish infected with ORF134 deleted virus versus fish infected with the control parental or revertant strains. All together, the results of the present study demonstrate that the IL-10 homologue encoded by CyHV-3 is essential neither for viral replication in vitro nor for virulence in common carp.
\end{abstract}

\section{Introduction}

Koi herpesvirus (KHV), also known as cyprinid herpesvirus 3 (CyHV-3; species Cyprinid herpesvirus 3, genus Cyprinivirus, family Alloherpesviridae, order Herpesvirales), is the etiological agent of an emerging and mortal disease in common (Cyprinus carpio carpio) and koi (Cyprinus carpio koi) carp [1,2]. Since its emergence, in the late 1990s, this highly contagious and dreadful disease has caused severe economic losses in both common and koi carp culture industries worldwide [3-5].

The genome of CyHV-3 comprises a linear doublestranded DNA sequence of $295 \mathrm{kbp}$ [6], similar to that of cyprinid herpesvirus 1 and 2 (CyHV-1 and CyHV-2) [7,8], but larger than those of other members of the order

\footnotetext{
* Correspondence: a.vdplasschen@ulg.ac.be

${ }^{1}$ Immunology-Vaccinology (B43b), Department of Infectious and Parasitic Diseases (B43b), Faculty of Veterinary Medicine, University of Liège, Liège B4000, Belgium

Full list of author information is available at the end of the article
}

Herpesvirales which generally range from 125 to $240 \mathrm{kbp}$. Phylogenetic analysis of the CyHV-3 genome sequence led to its classification in the new family Alloherpesviridae encompassing herpesviruses of fish and amphibians $[9,10]$. The CyHV-3 genome contains 155 potential proteincoding open reading frames (ORFs), some of which have relatives in other herpesviruses, and a few of which have relatives in poxviruses, iridoviruses and other large DNA viruses $[6,8,11]$. Interestingly, CyHV-3 genome encodes proteins potentially involved in immune evasion mechanisms such as, for example, TNF receptor homologues (encoded by ORF4 and ORF12) and an IL-10 homologue (encoded by ORF134) [6].

Cellular IL-10 has been described in a wide range of vertebrate species, including fish $[12,13]$. It is a pleiotropic immunomodulatory cytokine with both immunostimulating and immunosuppressive properties [14]; however, IL-10 is generally described as an immunosuppressive cytokine. It 
inhibits expression of a large number of cytokines as, for example, TNF- $\alpha$, IFN- $\gamma$, IL-1 $\beta$, IL-2, IL-3, IL-6, and MHC class II [15-17]. Many viruses exploit the immunosuppressive properties of IL-10 to evade immune recognition either by up-regulation of host IL-10 or by expression of virally encoded IL-10 homologues (vIL-10s) [14,18,19].

Virally encoded IL-10 homologues have been reported in members of the Poxviridae family and the Herpesvirales order [19-21]. Among the Herpesvirales order, vIL-10s have been described in members of the Herpesviridae (e.g. human cytomegalovirus [HCMV] and Epstein-Barr virus [EBV]) and more recently in the family Alloherpesviridae (Anguilid herpesvirus 1 [AngHV-1] and CyHV-3) [22]. While the role of vIL-10s has been demonstrated in the pathogenesis of one Poxviridae and one Herpesviridae [23-25]; this has not yet been investigated in the family Alloherpesviridae. However, a very recent study suggested that the IL-10 homologue encoded by CyHV-3 ORF134 could play a role in the pathogenesis. Firstly, it has been demonstrated that this ORF is transcribed in infected fish maintained at permissive and even restrictive temperature [26]. Secondly, it has been shown that injection of CyHV-3 ORF134 mRNA into zebrafish embryos increased the number of lysozyme-positive cells to a similar degree as zebrafish IL-10 [26]; an effect that was inhibited by down regulation of the IL-10 receptor long chain using a specific morpholino [26].

The present study was devoted to CyHV-3 ORF134 encoding an IL-10 homologue. In vitro studies demonstrated that ORF134 is expressed as a spliced early-late gene and that its expression product is the second most abundant viral protein in the CyHV-3 secretome. Taking advantage of the recent BAC cloning of $\mathrm{CyHV}-3$ as an infectious bacterial artificial chromosome (BAC), a strain deleted for ORF134 and a derived revertant strain were produced. Comparison of these strains demonstrated that ORF134 is essential neither for CyHV-3 replication in vitro nor for virulence in common carp.

\section{Materials and methods}

\section{Cells and viruses}

Cyprinus carpio brain cells (CCB) were cultured in minimum essential medium (MEM) (Invitrogen, Merelbeke, Belgium) containing $4.5 \mathrm{~g} / \mathrm{L}$ glucose (D-glucose monohydrate; Merck, Darmstadt, Germany) and 10\% fetal calf serum (FCS). Cells were cultured at $25{ }^{\circ} \mathrm{C}$ in a humid atmosphere containing 5\% $\mathrm{CO}_{2}$. The CyHV-3 FL strain was isolated from the kidney of a fish that died from CyHV-3 infection (CER, Marloie, Belgium) [27].

\section{Determination of ORF134 kinetic class of transcription}

These experiments were performed as described elsewhere [28]. Briefly, monolayers of CCB cells in 24-well plates were pre-incubated for $2 \mathrm{~h}$ before infection with cycloheximide (CHX) (100 $\mu \mathrm{g} / \mathrm{mL})$ (Sigma-Aldrich, Saint Louis, Missouri, USA) or phosphonoacetic acid (PAA) (300 $\mathrm{\mu g} / \mathrm{mL})$ (Sigma-Aldrich), the inhibitors of de novo protein synthesis or viral DNA polymerase, respectively. After removal of the medium, cells were infected with CyHV-3 FL strain at a multiplicity of infection (MOI) of 0.1 plaque forming unit (PFU) per cell in presence of inhibitors. After an incubation of $2 \mathrm{~h}$, cells were overlaid with fresh medium containing the inhibitors. At 6, 8 and $12 \mathrm{~h}$ after inoculation cells were harvested and treated for RT-PCR analysis of gene expression (see below). CyHV-3 ORF3 (immediate early [IE]), ORF55 (early [E]) and ORF78 (late [L]) were used as reference gene of the three kinetic classes [29,30].

\section{Transcriptional analysis by RT-PCR}

Cytoplasmic RNA was isolated from cells using the RNeasy Mini Kit (Qiagen, Venlo, Netherlands) with on column DNase I digestion. cDNA was synthetized from $1 \mu \mathrm{g}$ of RNA using iScript ${ }^{\mathrm{m}}$ cDNA Synthesis Kit (BioRad, Nazareth Eke, Belgium). Finally, PCRs were performed with the primers listed in Table 1 (see RTPCR column).

\section{Production of concentrated cell supernatant}

CCB cells were infected with CyHV-3 FL strain at a MOI of 0.05 PFU per cell using serum free culture medium. Cell supernatants were collected $72 \mathrm{~h}$ postinoculation and then submitted to two cycles of centrifugation at $4{ }^{\circ} \mathrm{C}$ (clarification at $2000 \mathrm{~g}$ for $15 \mathrm{~min}$ followed by pelleting of viral particles at $100000 \mathrm{~g}$ for $2 \mathrm{~h}$ through a $30 \%$ sucrose gradient). The supernatant was then concentrated 25-fold by centrifugation (2000 g, 75 min, $4{ }^{\circ} \mathrm{C}$ ) through an Amicon Ultra-15 centrifugal filter unit (3K NMWL; Merck Millipore, Billerica Massachusetts, USA) and stored at $-80{ }^{\circ} \mathrm{C}$ until use.

\section{D-LC MS/MS proteomic approach}

Proteomic analyses were performed using 2D-LC MS/MS workflow as described previously [31]. Briefly, proteins were reduced at $4{ }^{\circ} \mathrm{C}$ for $1 \mathrm{~h}$ with $10 \mathrm{mM}$ DTT and alkylated by incubation with 25 mMiodoacetamide at $4{ }^{\circ} \mathrm{C}$ for $1 \mathrm{~h}$ in the dark. Proteins were recovered through acetone precipitation and digested with trypsin at an enzyme:

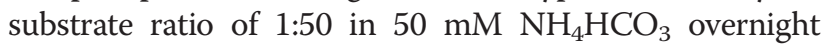
at $37{ }^{\circ} \mathrm{C}$. Tryptic peptides $(25 \mu \mathrm{g})$ were analysed by bidimensional (SCX-RP) chromatography and online MS/ MS, as described elsewhere [32], except that only 3 successive salt plugs of 25, 100 and $800 \mathrm{mM} \mathrm{NH}_{4} \mathrm{Cl}$ were used. Peptides were analyzed using the "peptide scan" option of an HCT ultra ion Trap (Bruker, Evere, Belgium), consisting of a full-scan mass spectrometry (MS) and MS/ MS scan spectrum acquisitions in ultrascan mode (26 000 $\mathrm{m} / \mathrm{z}$ sec-1). Peptide fragment mass spectra were acquired 
Table 1 Primers and probes.

\begin{tabular}{|c|c|c|c|c|c|}
\hline Targeted gene & Primer/probe name & & & Sequence $\left(5^{\prime}-3^{\prime}\right)$ & Accession $\mathrm{n} /$ reference \\
\hline \multicolumn{2}{|c|}{ Primers for PCR and RT-PCR } & PCR & RT-PCR & & \\
\hline \multirow[t]{2}{*}{ CyHV-3 ORF3 } & ORF3InF & & $\bullet$ & TATGCCCACATGATGCTGTT & DQ657948 \\
\hline & ORF3InR & & $\bullet$ & CAGTCAGACCCTTCCTCTGC & \\
\hline \multirow[t]{4}{*}{ CyHV-3 ORF55 } & ORF55InF & $\bullet$ & & AGCGCTACACCGAAGAGTCC & \\
\hline & ORF55stopR & $\bullet$ & & TCACAGGATAGATATGTTACAAG & \\
\hline & ORF55ATGF & & $\bullet$ & ATGGCTATGCTGGAACTGG & \\
\hline & ORF55InR & & $\bullet$ & GGCGCACCCAGTAGATTATG & \\
\hline \multirow[t]{2}{*}{ CyHV-3 ORF78 } & ORF78InF & & $\bullet$ & TGGACGACGAACACCCTTC & \\
\hline & ORF78InR & & $\bullet$ & GGTAGAGGGTACAACCACG & \\
\hline \multirow[t]{2}{*}{ CyHV-3 ORF132 } & ORF132InF & & $\bullet$ & GGATCCGTITTCTGGGTCTG & \\
\hline & ORF132InR & & $\bullet$ & СТCAATCCCTCACCGACCTC & \\
\hline \multirow[t]{2}{*}{ CyHV-3 ORF133 } & ORF133InF & & $\bullet$ & GACGAGATCCCTATCCGCAG & \\
\hline & ORF133InR & & $\bullet$ & GACCTCGGGTATGGTCGGTA & \\
\hline \multirow[t]{6}{*}{ CyHV-3 ORF134 } & ORF134stopF & & $\bullet$ & TCAATGTTGCGCTTGGTITC & \\
\hline & ORF134ATGR & & $\bullet$ & ATGTTCCTTGCAGTGCTAC & \\
\hline & ORF134InF & $\bullet$ & & GGTITCTCTITGTAGTITCCG & \\
\hline & ORF134InR & $\bullet$ & & CACCCCAACTITTGAGACAAC & \\
\hline & ORF134outseqF & $\bullet$ & & GTCAACATGGACGAGCGTGA & \\
\hline & ORF134outseqR & $\bullet$ & & GTGGGGATATCAAACACGCA & \\
\hline \multirow[t]{2}{*}{ CyHV-3 ORF135 } & ORF135InF & & $\bullet$ & ACACCACCAACGAGACATGC & \\
\hline & ORF135InR & & $\bullet$ & CTITCGGACCAGAAGACCG & \\
\hline \multirow[t]{2}{*}{ Carp $\beta$-actin } & Actin-F & & $\bullet$ & ATGTACGTTGCCATCCAGGC & M24113 \\
\hline & Actin-R & & $\bullet$ & GCACCTGAACCTCTCATTGC & \\
\hline \multicolumn{6}{|c|}{ Primers for amplification of recombination cassettes } \\
\hline \multirow[t]{6}{*}{$\mathrm{H} 1$-ga/K-H2 cassette } & 134 ga/K F & & & ATGTTCCTTGCAGTGCTACTAACCG & Warming et al. [34] \\
\hline & & & & CGACCATCTTCTTCGAGGCTCGGGG & \\
\hline & & & & CCTGTTGACAATTAATCATCGGCA & \\
\hline & 134 galK R & & & TCAATGTITGCGCTTGGTITCATG & \\
\hline & & & & TTCTTGACGTCTTTTGGACCAGGA & \\
\hline & & & & TCAGCACTGTCCTGCTCCTT & \\
\hline $\mathrm{H} 1-\mathrm{ORF} 134-\mathrm{H} 2$ & $\mathrm{H} 1 \mathrm{~F}$ & & & GCTCATCAATCGCAGCAGCA & DQ657948 \\
\hline \multicolumn{6}{|l|}{ cassette } \\
\hline & $\mathrm{H} 2 \mathrm{R}$ & & & CAAGCCATTATCCTGTTGGG & \\
\hline \multicolumn{6}{|c|}{ Primers and probes for real-time TaqMan PCR quantification of CyHV-3 genome } \\
\hline \multirow[t]{3}{*}{ CyHV-3 ORF89 } & KHV-86F & & & GACGCCGGAGACCTTGTG & AF411803 \\
\hline & KHV-163R & & & CGGGTTCTTATTITTGTCCTTGTT & \\
\hline & KHV-109P & & & (6FAM)CTTCCTCTGCTCGGCGAGCACG(BHQ1) & \\
\hline \multirow[t]{3}{*}{ Carp glucokinase } & CgGluc-162F & & & ACTGCGAGTGGAGACACATGAT & AF053332 \\
\hline & CgGluc-230R & & & TCAGGTGTGGAGCGGACAT & \\
\hline & CgGluc-185P & & & (6FAM)AAGCCAGTGTCAAAATGCTGCCCACT(BHQ1) & \\
\hline \multicolumn{6}{|c|}{ Primers for RT-qPCR analysis of carp gene expression } \\
\hline \multirow[t]{2}{*}{405} & $40 S-F$ & & & CCGTGGGTGACATCGTTACA & AB012087 \\
\hline & $40 S-R$ & & & TCAGGACATTGAACCTCACTGTCT & \\
\hline
\end{tabular}


Table 1 Primers and probes. (Continued)

\begin{tabular}{|c|c|c|c|}
\hline \multirow[t]{2}{*}{$\overline{I L}-1 \beta$} & $I L-1 \beta-F$ & AAGGAGGCCAGTGGCTCTGT & AJ245635 \\
\hline & $I L-1 \beta-R$ & CCTGAAGAAGAGGAGGCTGTCA & \\
\hline \multirow[t]{2}{*}{ TNF-a1 and 2} & TNF-a1 and 2-F & GCTGTCTGCTTCACGCTCAA & AJ311800 \\
\hline & TNF-a1 and 2-R & CCTTGGAAGTGACATTTGCTIT & \\
\hline \multirow[t]{2}{*}{$\mathrm{CXCa}$} & CXCa-F & CTGGGATTCCTGACCATTGGT & AJ421443 \\
\hline & CXCa-R & GTTGGCTCTCTGTTTCAATGCA & \\
\hline \multirow[t]{2}{*}{ IL-10 } & IL-10-F & CGCCAGCATAAAGAACTCGT & AB110780 \\
\hline & IL-10-R & TGCCAAATACTGCTCGATGT & \\
\hline \multirow[t]{2}{*}{ IFNY-2 } & $\mathrm{IFNY}-2-\mathrm{F}$ & TCTTGAGGAACCTGAGCAGAA & AM168523 \\
\hline & IFNY-2-R & TGTGCAAGTCTITCCTTTGTAG & \\
\hline \multirow[t]{2}{*}{$\| \mathrm{L}-6$} & IL-6M17-F & CACATTGCTGTGAGGGTGAA & AY102633 \\
\hline & IL-6M17-R & GCATCCATAGGCTTTCTGCT & \\
\hline
\end{tabular}

Underlined: 50bp corresponding to CyHV-3 sequence.

in data-dependent AutoMS (2) mode with a scan range of $100-2,800 \mathrm{~m} / \mathrm{z}$, three averages, and 5 precursor ions selected from the MS scan $300-1500 \mathrm{~m} / \mathrm{z}$. Precursors were actively excluded within a $0.5 \mathrm{~min}$ window, and all singly charged ions were excluded. Peptide peaks were detected and deconvoluted automatically using Data Analysis 2.4 software (Bruker). Mass lists in the form of Mascot Generic Files were created automatically and used as the input for Mascot MS/MS Ions searches of the NCBInr database release 20120809 using an in-house Mascot 2.2 server (Matrix Science). The default search parameters used were: Taxonomy $=$ Bony vertebrates or Cyprinivirus; Enzyme $=$ Trypsin; Maximum missed cleavages $=1$; Fixed modifications $=$ Carbamidomethyl $(\mathrm{C})$; Variable modifications $=$ Oxidation $(\mathrm{M})$; Peptide tolerance \pm 1.2 Dalton (Da); MS/MS tolerance $\pm 0.6 \mathrm{Da}$; Peptide charge $=2+$ and $3+$; Instrument $=$ ESI-TRAP. All data were also searched against the NCBI bony vertebrate database in order to detect host proteins. Only proteins identified with $\mathrm{p}$ value lower than 0.05 were considered, and single peptide identifications were systematically evaluated manually. In addition, the emPAI [33] was calculated to estimate protein relative abundance in the culture supernatant.

\section{Production of CyHV-3 ORF134 recombinants}

CyHV-3 recombinants were produced using prokaryotic recombination technologies (Figure 1). The FL BAC plasmid was used as parental plasmid [27]. In this plasmid, the BAC cassette is inserted in ORF55 encoding thymidine kinase (TK). ORF134 recombinant plasmids were produced using two-steps galactokinase gene ( $\mathrm{gal}$ /K) positive/ negative selection in bacteria as described previously [34]. The first recombination process (galK positive selection) consisted to replace ORF134 by galK resulting in the FL BAC ORF134 Del galK plasmid. Recombination was achieved using the H1-galK-H2 recombination cassette (Figure 1b) which consisted of the galK gene flanked by 50-bp sequences homologous to CyHV-3 genome regions flanking ORF134 deletion (Figure 1a). H1-galK-H2 recombination cassette was produced by PCR (primers 134 galK $\mathrm{F}$ and 134 galK R) using the pgalK vector as template. Primer 134 galK F consisted of nucleotides 229836229885 (50bp) of CyHV-3 genome and 1-24 (24bp) of the pgalK vector. Primer 134 galK R consisted of nucleotides 229262-229311 (50bp) of the CyHV-3 genome and nucleotides 1212-1231 (20bp) of the pgalK vector (Table 1). The 50-bp sequences of the H1-galK-H2 corresponding to CyHV-3 genome were used to target homologous recombination in bacteria. The second recombination process (galK negative selection) consisted to remove the galK gene (FL BAC ORF134 Del plasmid) or to replace the galK gene by CyHV-3 wild type ORF134 sequence (FL BAC ORF134 Rev plasmid) (Figure 1). The FL BAC ORF134 Del plasmid was obtained by recombination with the H1$\mathrm{H} 2$ cassette (Figure $1 \mathrm{~b}$ ). This cassette was synthesized and consisted of $200 \mathrm{bp}$ of CyHV-3 genome upstream and downstream of ORF134 deletion, respectively. The FL BAC ORF134 Rev plasmid was produced by recombination with the H1-ORF134-H2 cassette. This cassette was produced by PCR (primers H1F and H2R) using CyHV-3 FL DNA as template corresponding to nucleotides 229057229076 and nucleotides 230056-230075 of CyHV-3 genome, respectively. To reconstitute infectious virus encoding a wild type TK locus (removal of the BAC cassette), the BAC plasmids (FL BAC, FL BAC ORF134 Del and FL BAC ORF134 Rev) were co-transfected with the pGEMT-TK plasmid (molecular ratio, 1:75) into CCB cells [27]. Plaque negative for enhanced green fluorescent protein (EGFP) expression (the BAC cassette encodes an EGFP expression cassette) were picked and amplified.

\section{Southern blotting}

Southern blot analysis of recombinant viruses was performed as described previously $[27,35]$. PCRs were 


\section{A}

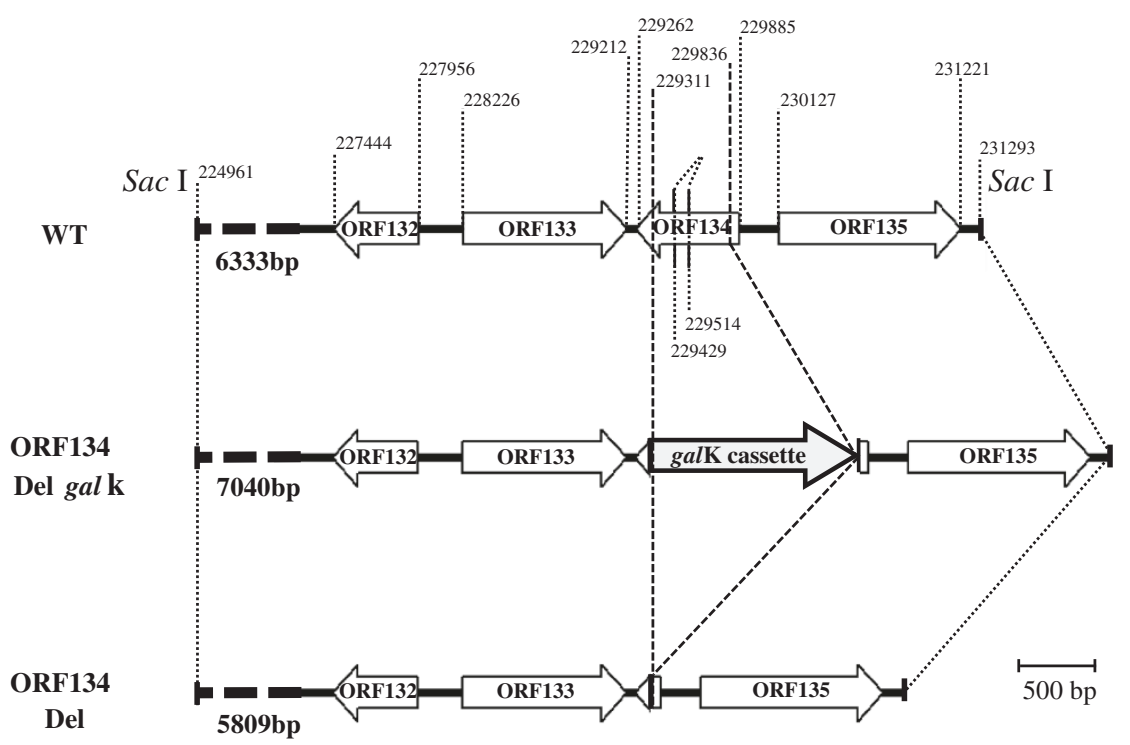

B

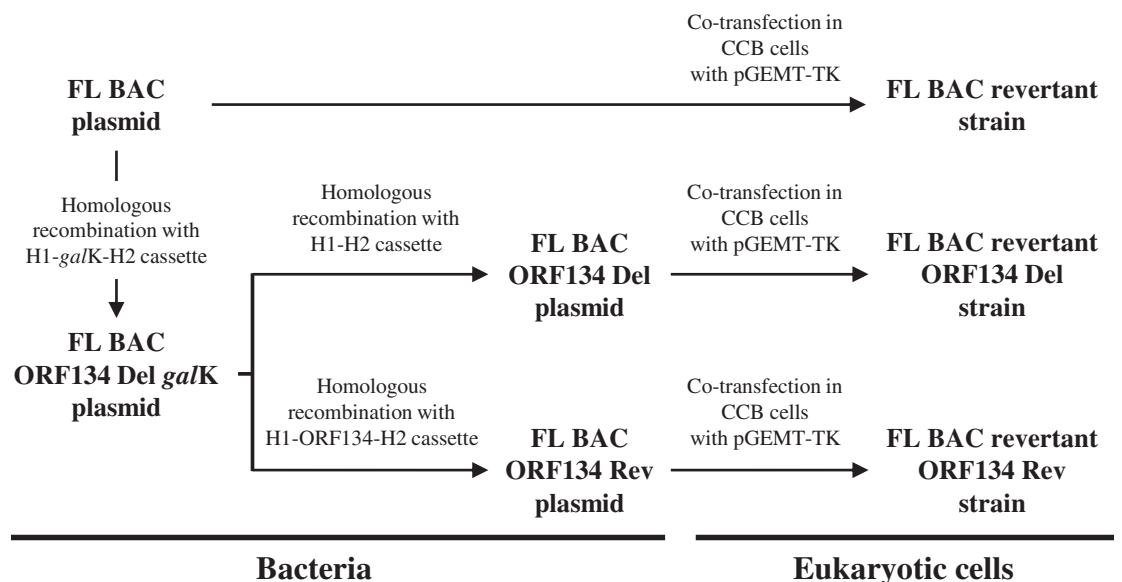

Figure 1 Schematic representation of the strategy used to produce CyHV-3 FL BAC ORF134 recombinants. (A) The region of CyHV-3 genome encoding ORF134 is illustrated for wild type (WT), ORF134 Del galK and ORF134 Del genotypes. (B) Flow chart of stages performed to produce FL BAC ORF134 recombinant plasmids and to reconstitute virus strains.

performed to produce ORF55 probe (primers ORF55InF and ORF55stopR) and ORF134Del probe (primers ORF134InF and ORF134InR) using the CyHV-3 FL genome as a template (Table 1).

\section{Multi-step growth curves}

Triplicate cultures of CCB cells were infected at a MOI of 0.5 PFU per cell. After an incubation period of $2 \mathrm{~h}$, cells were washed with phosphate-buffered saline (PBS) and then overlaid with Dulbecco's modified essential medium (DMEM, Invitrogen) containing $4.5 \mathrm{~g}$ of glucose/liter and $10 \%$ FCS. Supernatant of infected cultures was harvested at successive intervals after infection and stored at $-80{ }^{\circ} \mathrm{C}$. The amount of infectious virus was determined by plaque assay on CCB cells as described previously [35].
Fish

Common carp (Cyprinus carpio carpio) (CEFRA, University of Liège, Belgium), were kept in 60 -liter tanks at $24{ }^{\circ} \mathrm{C}$. Microbiological, parasitical and clinical examinations of the fish just before the experiments demonstrated that these fish were fully healthy.

\section{CyHV-3 inoculation of carp}

For viral inoculation mimicking natural infection, fish were kept for $2 \mathrm{~h}$ in water containing CyHV-3. At the end of the incubation period, fish were returned to larger tanks. In some experiments, fish that survived the primary infection were challenged 42 days after inoculation by cohabitation with fish that were infected by immersion in water containing $200 \mathrm{PFU} / \mathrm{mL}$ of the FL strain just before their release into the tank to be challenged. Two freshly infected fish were released per tank to be challenged. The 
animal study was accredited by the local ethics committee of the University of Liège, Belgium (Laboratory accreditation $\mathrm{N}^{\circ} 1610008$, protocol $\mathrm{N}^{\circ} 810$ ).

\section{Quantification of virus genome copies in organs by real- time TaqMan PCR}

Virus genome quantitation was performed by real-time TaqMan PCR as described elsewhere [36]. The primers and the probes used are presented in Table 1. Two sets of primers were used to amplify fragments of CyHV-3 ORF89 and carp glucokinase genes. The amplicons were cloned into the pGEM-T Easy vector and the resulting plasmids were used to generate standard curves by running reactions with $10^{1}$ to $10^{10}$ plasmid molecules. DNA was isolated using a DNA mini kit (Qiagen) from $25 \mathrm{mg}$ of organs stored at $-80{ }^{\circ} \mathrm{C}$ in RNAlater (Invitrogen). The reaction mix contained $1 \times$ iQSupermix (Bio-Rad), $200 \mathrm{nM}$ of each primer, $400 \mathrm{nM}$ of fluorescent probe and $250 \mathrm{ng}$ of DNA. The analyses were performed using a C1000 Touch Thermal cycler (Bio-Rad). All real-time TaqMan PCRs for CyHV-3 DNA were run with equal amounts of DNA estimated by the real-time TaqMan PCR performed on carp glucokinase gene.

Quantification of carp gene expression in spleen by RT-qPCR Total RNA was isolated from spleens stored at $-80{ }^{\circ} \mathrm{C}$ in RNALater ${ }^{\circ}$ (Ambion', Invitrogen, Merelbeke, Belgium) using TRI reagent ${ }^{\circ}$ (Ambion ${ }^{\circ}$, Invitrogen), including DNase I digestion and RNA purification using RNeasyMinElute Cleanup Kit (Qiagen). cDNA was synthetized from $1 \mu \mathrm{g}$ of RNA using iScriptcDNA Synthesis Kit (Bio-Rad). The primers used for RT-qPCR were described previously [37] and are listed in Table 1. The RT-qPCR master-mix was prepared as follows: $1 \times \mathrm{IQ}^{\mathrm{Tw}} \mathrm{SYBR}^{\circ}$ Green Supermix (BioRad), $200 \mathrm{nM}$ of each primer, $5 \mu \mathrm{L}$ of $25 \times$ diluted cDNA and sterile water to a final volume of $25 \mu \mathrm{L}$. The amplification program included an initial denaturation at $95{ }^{\circ} \mathrm{C}$ for $10 \mathrm{~min}$, followed by 40 cycles with denaturation at $95^{\circ} \mathrm{C}$ for $15 \mathrm{~s}$, annealing at $58^{\circ} \mathrm{C}$ for $30 \mathrm{~s}$ and elongation at $72{ }^{\circ} \mathrm{C}$ for $30 \mathrm{~s}$. At the end, the dissociation stage was performed $\left(95^{\circ} \mathrm{C}\right.$ for for $\left.10 \mathrm{~s}\right)$ and the melt curve was obtained by increasing the temperature from $60^{\circ} \mathrm{C}$ to $95^{\circ} \mathrm{C}$ with a rate of $0.5{ }^{\circ} \mathrm{C}$ per $5 \mathrm{~s}$. Fluorescence data from RT-qPCR experiments were analyzed using the CFX96 real-time system and exported to Microsoft Excel. The threshold cycle (Ct) was determined using the Auto method for all runs. The expression of analyzed genes was calculated using the $2^{-\Delta \Delta \mathrm{Ct}}$ method [38]. The $40 \mathrm{~S}$ ribosomal protein S11 was used as a reference gene.

\section{Histological analysis}

Organs from mock-infected or infected carp were fixed in $4 \%$ buffered formalin and embedded in paraffin blocks. Sections of $5 \mu \mathrm{m}$ were stained with haematoxylin and eosin prior to microscopic analysis [39].

\section{Statistical analyses}

Multi-step growth curves data expressed as mean titer \pm standard deviation (SD) were analyzed for significance of differences $(p<0.05)$ using one-way ANOVA. The differences in mortality induced by the CyHV-3 strains tested were analyzed using Kaplan and Meier survival analysis. Significant differences $(p<0.05)$ in virus load between fish infected with the different CyHV-3 strains at each sampling point were assessed using one-way ANOVA followed by Holm-Sidak test when data were normally distributed, or with the non-parametric Kruskal-Wallis test followed by Tukey test when they were not. Significant differences $(p<0.05)$ in RT-qPCR gene expression between CyHV-3 infected and mock-infected fish, as well as between fish infected with different CyHV-3 strains at each sampling point were assessed using oneway ANOVA followed by Holm-Sidak test in cases where the data were normally distributed, or with the non-parametric Kruskal-Wallis test followed by Dunn's test when they were not

\section{Results}

\section{CyHV-3 ORF134 kinetic class of expression}

Two independent studies have demonstrated that CyHV-3 ORF134 is transcribed during viral replication in vitro thereby meeting the criteria for being a gene $[26,29]$. It has been predicted to contain an $84 \mathrm{bp}$ intron flanked by 2 exons encoding a 179 amino acid product (GenBank accession number DQ657948). Here, we used CHX and PAA to identify the transcriptional class of ORF134 (Figure 2). This experiment revealed that ORF134 expression is prevented by CHX and reduced but not prevented by PAA treatments, suggesting that ORF134 is an E-L gene. ORF3, ORF55 and ORF78 were used as controls in this experiment; the results presented in Figure 2 confirmed that they are IE, E and L genes, respectively. The absence of contaminant viral DNA in the mRNA preparations was confirmed by the absence of a PCR product when the reverse transcriptase was omitted from the reactions. Furthermore, the estimated molecular size of the major ORF134 RT-PCR product revealed that it was derived, from the amplification of cDNA (540 bp) rather than from the viral genome (624 bp). This observation is consistent with the earlier description of the ORF134 as a spliced gene [40,41]. However, a minor product corresponding to the unspliced transcript of ORF134 was also observed (see the faint 624 bp band in Figure 2). The classification of ORF134 as an E-L gene is consistent with the results published recently by Ilouze et al. who concluded that ORF134 is 


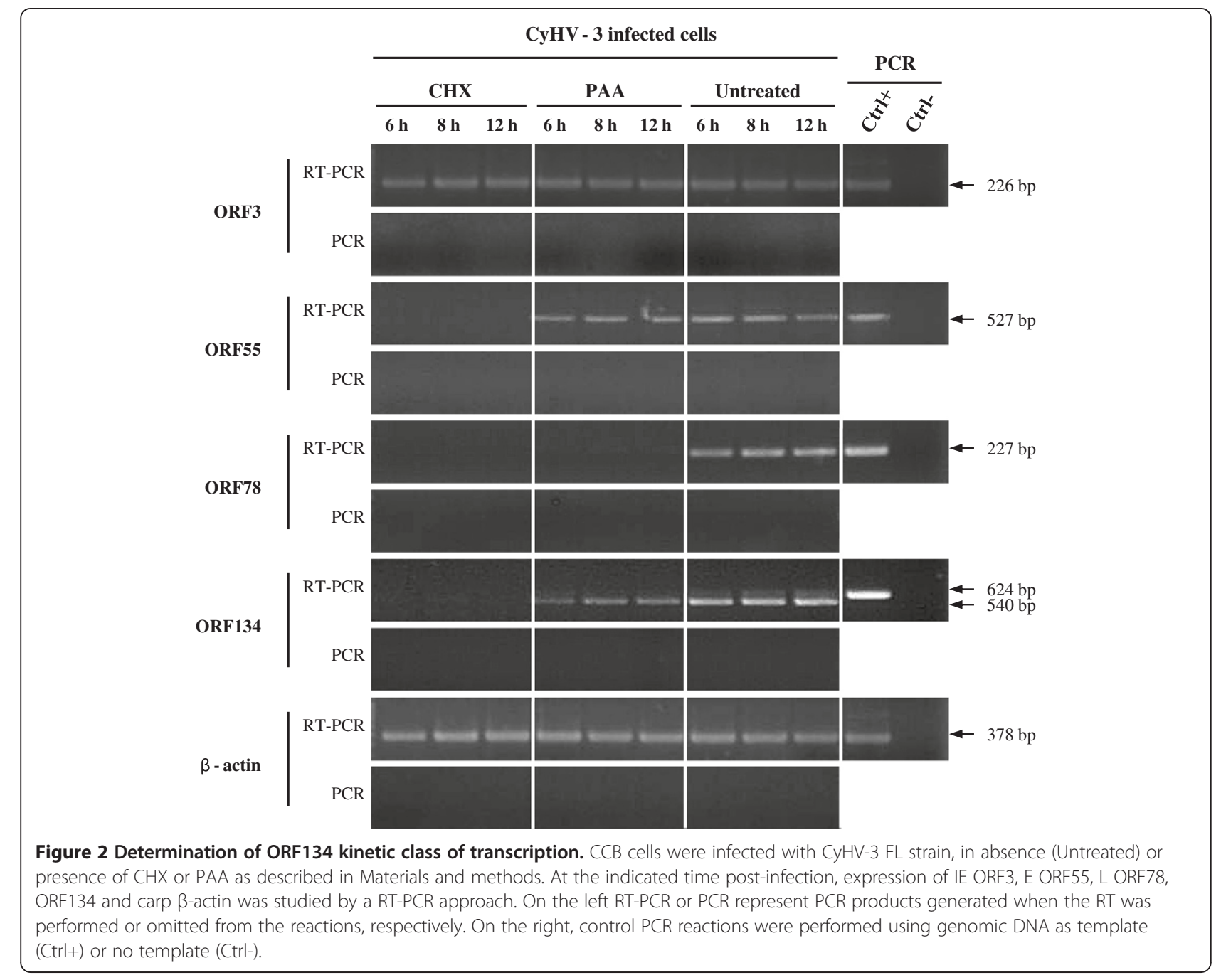

an E gene [29]. It is also consistent with the E expression reported for other vIL-10s $[40,41]$.

\section{CyHV-3 secretome}

While two independent studies have previously shown that ORF134 is transcribed during viral replication $[26,29]$, it is still to be determined whether ORF134 encodes a protein secreted from infected cells. To address this question, concentrated supernatant was produced from CyHV-3 infected CCB cultures and analyzed by 2D-LC MS/MS. Viral and cellular proteins identified by this approach are listed in Table 2. This list was restricted to proteins identified with $\mathrm{p}$ value lower than 0.05 as determined by the MASCOT program. Five viral and 46 cellular proteins were detected. CyHV-3 ORF12 and ORF134 were amongst the most abundant proteins in the sample as revealed by their relatively high emPAI scores (1.49 and 1.02, respectively). Only two cellular proteins had comparable scores (Beta-2-microglobulin and FK506 binding protein 1A, with emPAI scores of
1.79 and 1.39, respectively). ORF12 encodes a soluble TNF receptor superfamily homologue which, like ORF134, was expected to be secreted from infected cells. Three unique peptides covering $16 \%$ of the ORF134 sequence were sequenced (Figure 3a). These peptides were distributed throughout ORF134 sequence (Figure 3b). The divergence existing between CyHV-3 IL-10 and carp IL-10 excludes the hypothesis that the peptides detected could be derived from carp IL-10 rather than from CyHV-3 ORF134. In addition to CyHV-3 ORF12 and ORF134, three additional viral proteins (ORF52, ORF116 and ORF119) were detected in the CyHV-3 secretome. All three proteins are potential membrane proteins (Table 2). The presence of these putative membrane proteins in the CyHV-3 secretome cannot be explained by remaining viral particles in the prepared concentrated extracellular medium, as none of these proteins is structural [31]. It is also unlikely that the presence of these proteins reflects cell lysis resulting from the viral infection. Indeed, in such a case, a higher number of viral proteins would be expected, in 
Table 2 CyHV-3 and host proteins identified by 2D-LC MS/MS in the supernatant of CyHV-3 infected CCB cells.

\begin{tabular}{|c|c|c|c|c|c|c|}
\hline Database & $\begin{array}{l}\text { Accession } \\
\text { number }\end{array}$ & Description & $\begin{array}{r}\text { Predicted MW } \\
(\mathrm{kDa})\end{array}$ & $\begin{array}{r}\text { Mascot } \\
\text { score }\end{array}$ & $\begin{array}{r}\text { No. of matching } \\
\text { spectra }\end{array}$ & $\overline{\text { emPAI }}$ \\
\hline & & CyHV-3 proteins & & & & \\
\hline \multirow[t]{6}{*}{ Cyprinivirus } & gi|129560530 & ORF12, TNF receptor superfamily homologue & 19.2 & 671 & 14 & 1.49 \\
\hline & gi|129560652 & ORF134, Interleukin 10 homologue & 14.8 & 304 & 6 & 1.02 \\
\hline & gi|84181525 & ORF116, predicted membrane glycoprotein & 30.4 & 185 & 4 & 0.26 \\
\hline & gi|84181523 & $\begin{array}{l}\text { ORF119, putative uncharacterized protein containing an } \\
\text { hydrophobic region }\end{array}$ & 15.5 & 94 & 2 & 0.25 \\
\hline & gi|129560569 & ORF52, predicted membrane glycoprotein & 39.2 & 44 & 1 & 0.10 \\
\hline & & Host proteins (species origin) & & & & \\
\hline \multirow{34}{*}{$\begin{array}{l}\text { Bony } \\
\text { vertebrates }\end{array}$} & gi|122891218 & Novel protein (zgc:103659) (Danio rerio) & 51.7 & 410 & 13 & 0.42 \\
\hline & gi|136429 & Trypsin (Sus scrofa) & 25.1 & 281 & 9 & 0.53 \\
\hline & gi|297262447 & $\begin{array}{l}\text { Predicted keratin, type II cytoskeletal 1-like isoform } 6 \\
\text { (Macaca mulatta) }\end{array}$ & 65.3 & 268 & 3 & 0.12 \\
\hline & gi|37590349 & Enolase 1, alpha (D. rerio) & 47.4 & 255 & 8 & 0.35 \\
\hline & gi|326670662 & Predicted collagen alpha-3(VI) chain-like (D. rerio) & 11.3 & 227 & 8 & 0.17 \\
\hline & gi|51949771 & Fibronectin 1b (D. rerio) & 279.3 & 213 & 8 & 0.08 \\
\hline & gi|52218922 & Pigment epithelium-derived factor precursor (D. rerio) & 45.0 & 158 & 3 & 0.17 \\
\hline & gi|416696 & Beta-2-microglobulin (Cyprinus carpio) & 13.5 & 152 & 8 & 1.79 \\
\hline & gi|1351907 & Serum albumin (Bos taurus) & 71.2 & 149 & 11 & 0.36 \\
\hline & gi|395744345 & Predicted keratin, type II cytoskeletal 1 (Pongo abelii) & 25.8 & 139 & 3 & 0.15 \\
\hline & gi|229552 & Albumin (B. taurus) & 68.1 & 136 & 10 & 0.38 \\
\hline & gi|63102189 & Pgd protein (D. rerio) & 53.7 & 134 & 4 & 0.14 \\
\hline & gi|15718387 & Gelatinase (Paralichthys olivaceus) & 75.5 & 125 & 5 & 0.15 \\
\hline & gi|1703244 & Fructose-bisphosphate aldolase C (Carassius auratus) & 39.8 & 124 & 4 & 0.20 \\
\hline & gi|169154447 & Fibronectin 1 (D. rerio) & 275.6 & 117 & 5 & 0.05 \\
\hline & gi|15149946 & Procollagen type I alpha 1 chain (D. rerio) & 49.4 & 117 & 5 & 0.34 \\
\hline & gi|148726027 & Cadherin 11, osteoblast (D. rerio) & 88.9 & 112 & 5 & 0.13 \\
\hline & gi|4885063 & Fructose-bisphosphate aldolase C (Homo sapiens) & 39.8 & 107 & 2 & 0.20 \\
\hline & gi|28336 & Mutant beta-actin (beta'-actin) (H. sapiens) & 42.1 & 105 & 2 & 0.09 \\
\hline & gi|28317 & Unnamed protein product (H. sapiens) & 59.7 & 104 & 3 & 0.13 \\
\hline & gi|337758 & Pre-serum amyloid P component (H. sapiens) & 25.5 & 100 & 3 & 0.32 \\
\hline & gi|223582 & Histone H4 (H. sapiens) & 11.2 & 99 & 5 & 0.84 \\
\hline & gi|47971186 & Carp C1q-like molecule (C. carpio) & 20.3 & 98 & 2 & 0.19 \\
\hline & gi|223061 & Ubiquitin (Salmo sp.) & 8.5 & 92 & 4 & 0.31 \\
\hline & gi|27806751 & Alpha-2-HS-glycoprotein precursor (B. taurus) & 39.2 & 90 & 4 & 0.32 \\
\hline & gi|47086029 & Myristoylated alanine-rich C kinase substrate 2 (D. rerio) & 21.0 & 86 & 2 & 0.18 \\
\hline & gi|2133885 & $\mathrm{N}$-cadherin precursor (D. rerio) & 87.4 & 80 & 3 & 0.09 \\
\hline & gi|18859555 & Wnt inhibitory factor 1 precursor (D. rerio) & 43.2 & 79 & 3 & 0.09 \\
\hline & gi|34595971 & Prion-like protein 1 (C. carpio) & 55.6 & 75 & 2 & 0.14 \\
\hline & gi|208609649 & Collagen type I alpha 3 (C. auratus) & 137.7 & 75 & 1 & 0.03 \\
\hline & gi|47085905 & 14-3-3 protein beta/alpha-B (D. rerio) & 27.5 & 75 & 3 & 0.47 \\
\hline & gi|6644111 & Nucleoside diphosphate kinase-Z1 (D. rerio) & 17.4 & 72 & 2 & 0.22 \\
\hline & gi|16974825 & $\begin{array}{l}\text { Chain A, Solution Structure Of Calcium-Calmodulin N- } \\
\text { Terminal Domain (H. sapiens) }\end{array}$ & 8.5 & 70 & 2 & 0.49 \\
\hline & gi|41152406 & FK506 binding protein $1 \mathrm{~A}, 12 \mathrm{kDa}$ (D. rerio) & 11.8 & 69 & 3 & 1.39 \\
\hline
\end{tabular}


Table 2 CyHV-3 and host proteins identified by 2D-LC MS/MS in the supernatant of CyHV-3 infected CCB cells. (Continued)

\begin{tabular}{|c|c|c|c|c|c|}
\hline gi|189527793 & $\begin{array}{l}\text { Predicted neuroblast differentiation-associated protein } \\
\text { AHNAK (D. rerio) }\end{array}$ & 642.1 & 65 & 2 & 0.01 \\
\hline gi|37492 & Alpha-tubulin (H. sapiens) & 50.8 & 65 & 2 & 0.07 \\
\hline gi|33989505 & Tissue inhibitor of metalloproteinase $2 b$ (D. rerio) & 24.7 & 64 & 2 & 0.15 \\
\hline gi|8176557 & Heart fatty acid binding protein (Anguilla japonica) & 15.3 & 61 & 1 & 0.26 \\
\hline gi|37181 & $\begin{array}{l}\text { Tissue inhibitor of metalloproteinases, } \\
\text { Type- } 2 \text { (H. sapiens) }\end{array}$ & 21.4 & 59 & 2 & 0.18 \\
\hline gi|437972 & Fibrillin-2 (H. sapiens) & 334.8 & 59 & 1 & 0.01 \\
\hline gi|37367051 & Osteopontin (D. rerio) & 23.2 & 53 & 1 & 0.16 \\
\hline gi|45544646 & Cold inducible RNA binding protein isoform 2 (D. rerio) & 19.2 & 52 & 2 & 0.20 \\
\hline gi|51328294 & Fstl1b protein (D. rerio) & 39.6 & 50 & 1 & 0.09 \\
\hline gi|82245450 & Triosephosphate isomerase B (D. rerio) & 27.1 & 50 & 1 & 0.14 \\
\hline gi|34014734 & Clusterin (D. rerio) & 52.5 & 50 & 1 & 0.07 \\
\hline gi|47228578 & Unnamed protein product (Tetraodon nigroviridis) & 77.5 & 49 & 1 & 0.05 \\
\hline
\end{tabular}

particular the most abundant ones [31]. Several viral proteins are expressed as two different forms, a membraneanchored form and a secreted form, the latter generated by proteolytic cleavage of the former $[42,43]$. Further experiments are required to determine whether this phenomenon applies to the putative CyHV-3 membrane proteins detected in the secretome.

The MS data presented above demonstrate that CyHV-3 ORF134 encodes a protein that is abundantly secreted in the extracellular medium by infected cells. This observation is consistent with the hypothesis that ORF134 may be a functional IL-10 homologue playing a role in CyHV-3 pathogenesis [26].

\section{Production and characterization of CyHV-3 ORF134 recombinant strains}

In order to investigate subsequently the importance of ORF134 in virus replication in vitro and pathogenesis

A

\begin{tabular}{|c|c|c|c|c|}
\hline $\begin{array}{c}\text { Accession } \\
\text { number }\end{array}$ & Description & $\begin{array}{c}\text { Sequence } \\
\text { coverage }\end{array}$ & $\begin{array}{c}\text { Peptide } \\
\text { sequence }\end{array}$ & $\begin{array}{c}\text { Peptide } \\
\text { mascot score }\end{array}$ \\
\hline \multirow{2}{*}{ GI 129560652 } & \multirow{2}{*}{$\begin{array}{c}\text { CyHV-3 } \\
\text { ORF134 }\end{array}$} & \multirow{2}{*}{$16 \%$} & SEVDEIGDNLSR & 80 \\
\cline { 4 - 5 } & & & KSEVDEIGDNLSR & 52 \\
\cline { 3 - 5 } & & DSCVYLIGQTPQLLR & 50 \\
\hline
\end{tabular}

B

\begin{tabular}{|c|c|}
\hline \multirow{3}{*}{$\begin{array}{l}\text { CyHV-3 ORF134 } \\
\text { Cyprinus carpio IL-10 }\end{array}$} & -MFLAVLLTATIFFEARGAPATTPKDS---CVYLIGQTPQLLRQLRNAYQ \\
\hline & MVFSGVILSALVMFLLSDSAQCRRVDCKTDCCSFVEGFPVRLKELRSAYR \\
\hline & $:^{*} \cdot{ }^{*}:^{*}: *::^{*}$ \\
\hline CyHV-3 ORF134 & AI I GADGSGVDEDDMP IYPSDVMNELASTSVACDAIKKVLTMNIG-ILP- \\
\hline Cyprinus carpio IL-10 & EIQNFYES--NDDMEPLLDENVQQNINSP-YGCHVMNEILRFYLDTILPT \\
\hline & ${ }^{*} \ldots::::^{*}:::_{* * *}$ \\
\hline CyHV-3 ORF134 & NVTAAYPDK ZSEVDEIGDNLSR LHQNIVNCRDFLKCD----LPHWHQMAE \\
\hline Cyprinus carpio IL-10 & AVQKDHLHSKTPINSIGNIFQDLKRDMRKCRNYFSCQNPLEIAS IKNSYE \\
\hline & $: .^{*}::: *^{* *}:: .^{*}::::: *^{*}::: .^{*}:$ \\
\hline CyH & NYKEK-PMQGFSEMDFVFQSVEKFLVAKDVKNMKTKRKH \\
\hline Cyprinus ce & KMKEKGVSKAMGELDILFKYIEQYLASKRVKHL------ \\
\hline
\end{tabular}

Figure 3 Identification of CyHV-3 ORF134 by 2D-LC MS/MS in the supernatant of CyHV-3 infected CCB cells. (A) Data collected on ORF134 through 2D-LC MS/MS analysis of cell culture supernatant. (B) Sequential alignment of CyHV-3 ORF134 and Cyprinus carpio IL-10. Sequence coverage: detected peptides are presented in rectangles. 

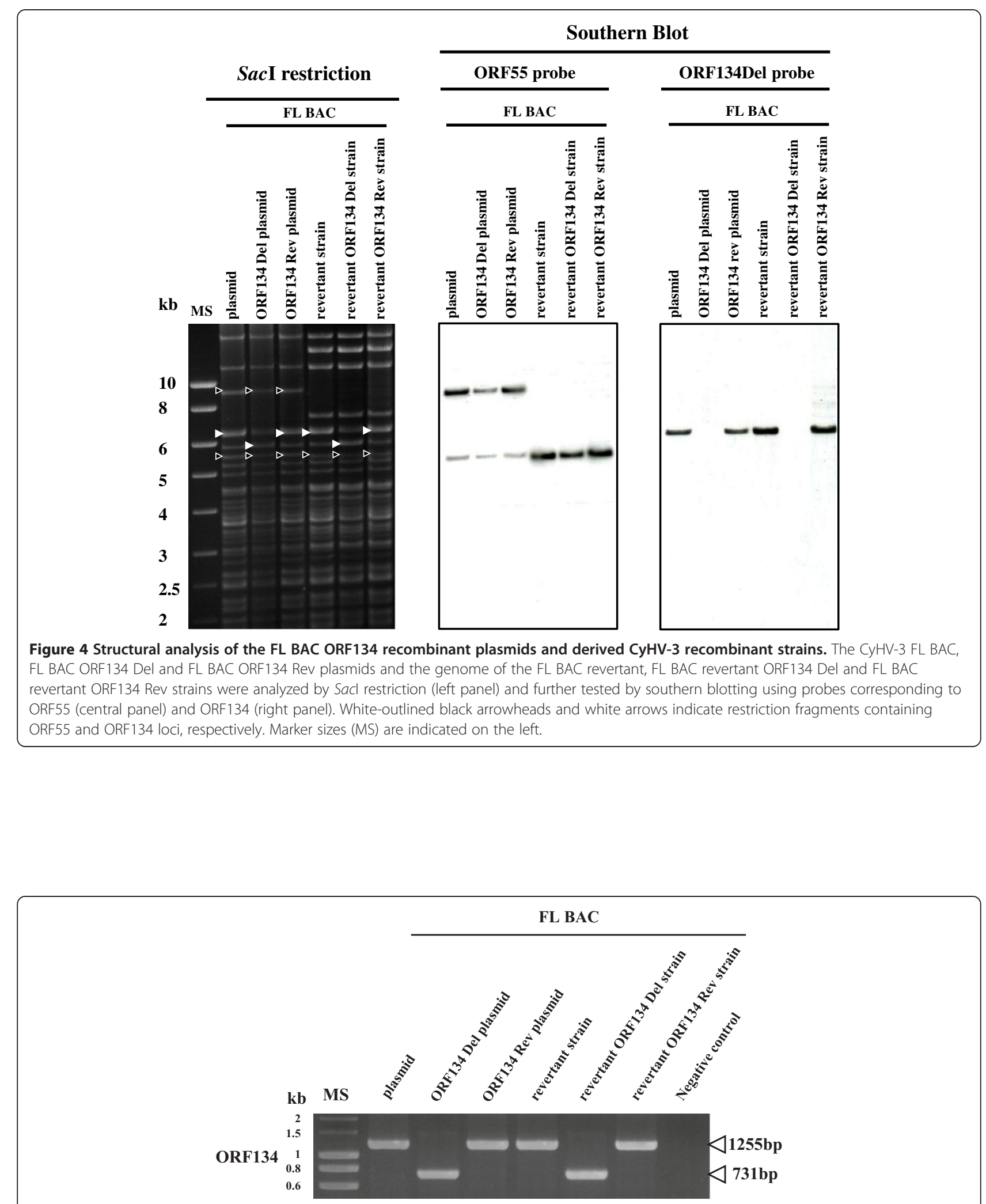

Figure 5 PCR analysis of the FL BAC ORF134 recombinant plasmids and derived CyHV-3 recombinant strains. The CyHV-3 FL BAC, FL BAC ORF134 Del and FL BAC ORF134 Rev plasmids and the genome of the FL BAC revertant, FL BAC revertant ORF134 Del and FL BAC revertant ORF134 Rev strains were analyzed by PCR using the forward primer ORF1340utsegF and the reverse primer ORF134outsegR (Table 1). MS are indicated on the left. 


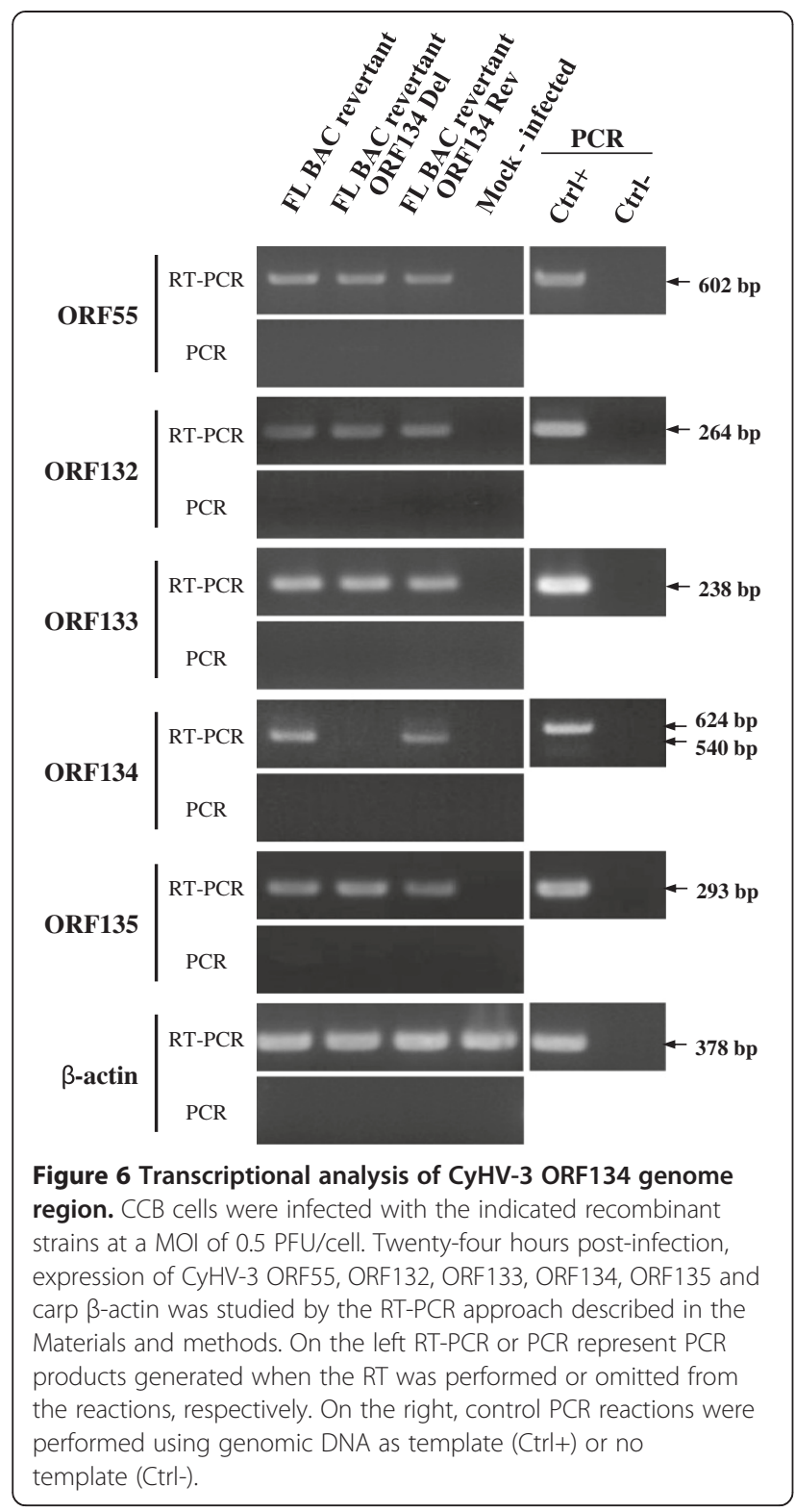

in vivo, a CyHV-3 strain deleted for ORF134 (FL BAC revertant ORF134 Del strain) and a revertant strain (FL BAC revertant ORF134 Rev strain) were produced using BAC cloning and prokaryotic recombination technologies as described in the Materials and methods (Figure 1). The FL BAC plasmid was used as parental plasmid. A wild type strain (FL BAC revertant strain) was also reconstituted from the FL BAC plasmid. The molecular structures of the recombinant strains produced were confirmed by a combined SacI restriction endonuclease and Southern blot approach targeting both ORF55 (the BAC cassette is inserted into the ORF55 locus) and ORF134 loci (Figure 4). In the three reconstituted strains, the ORF55 probe led to a single band

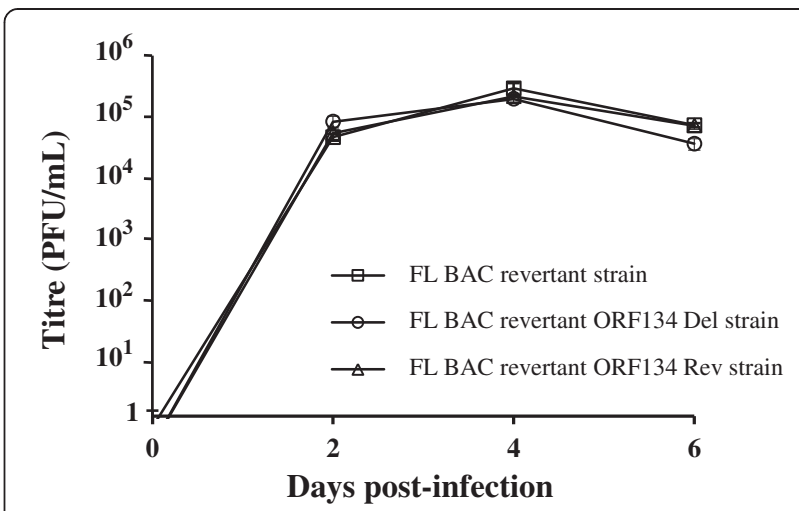

Figure 7 Effect of ORF134 deletion on viral growth in vitro. Replication kinetics of CyHV-3 ORF134 recombinant strains were compared with those of the FL BAC revertant strain using a multistep growth assay (see Materials and methods). The data presented are the means \pm standard errors of triplicate measurements.

corresponding to a $5.2 \mathrm{~kb}$ restriction fragment, demonstrating the reversion of ORF55 to wild type sequence (removal of the BAC cassette) [27]. In the FL BAC revertant and the FL BAC revertant ORF134 Rev, the ORF134Del probe led to a single band corresponding to a $6.3 \mathrm{~kb}$ restriction fragment consistent with the sequence of this region $(6333 \mathrm{~kb})$. The absence of signal for the FL BAC revertant ORF134 Del demonstrated the deletion of ORF134. The molecular structure of the recombinants and the absence of contamination between strains was also controlled by PCR (Figure 5) and sequencing of the regions used to target recombination (data not shown). All approaches confirmed that the resulting recombinants have the correct molecular structure. Finally, using a RT-PCR approach, we controlled the process so that the deletion did not markedly affect the transcription of the ORFs located upstream and downstream of ORF134: ORF132, ORF133 and ORF135 (Figures 1a and 6). In these experiments, transcription of ORF55 was used as reference. For the three recombinants tested, transcripts of $602 \mathrm{bp}, 264 \mathrm{bp}, 238 \mathrm{bp}$ and $293 \mathrm{bp}$ were observed in infected cells for ORF55, ORF132, ORF133 and ORF135, respectively. No transcript was detected in mock-infected cells. When RT was omitted from the reactions, the product seen in infected cells was not detected, indicating that this product did not result from amplification of contaminant viral DNA. The three strains tested led to comparable signals for the four ORFs. Transcription analysis of ORF134 revealed that the FL BAC revertant and the FL BAC revertant ORF134 Rev expressed this ORF comparably, while no signal was detected for the FL BAC revertant ORF134 Del. Together, the results presented above demonstrate that the recombinants produced have the correct molecular structure and that the deletion of ORF134 has no marked polar effect on neighbor genes. 


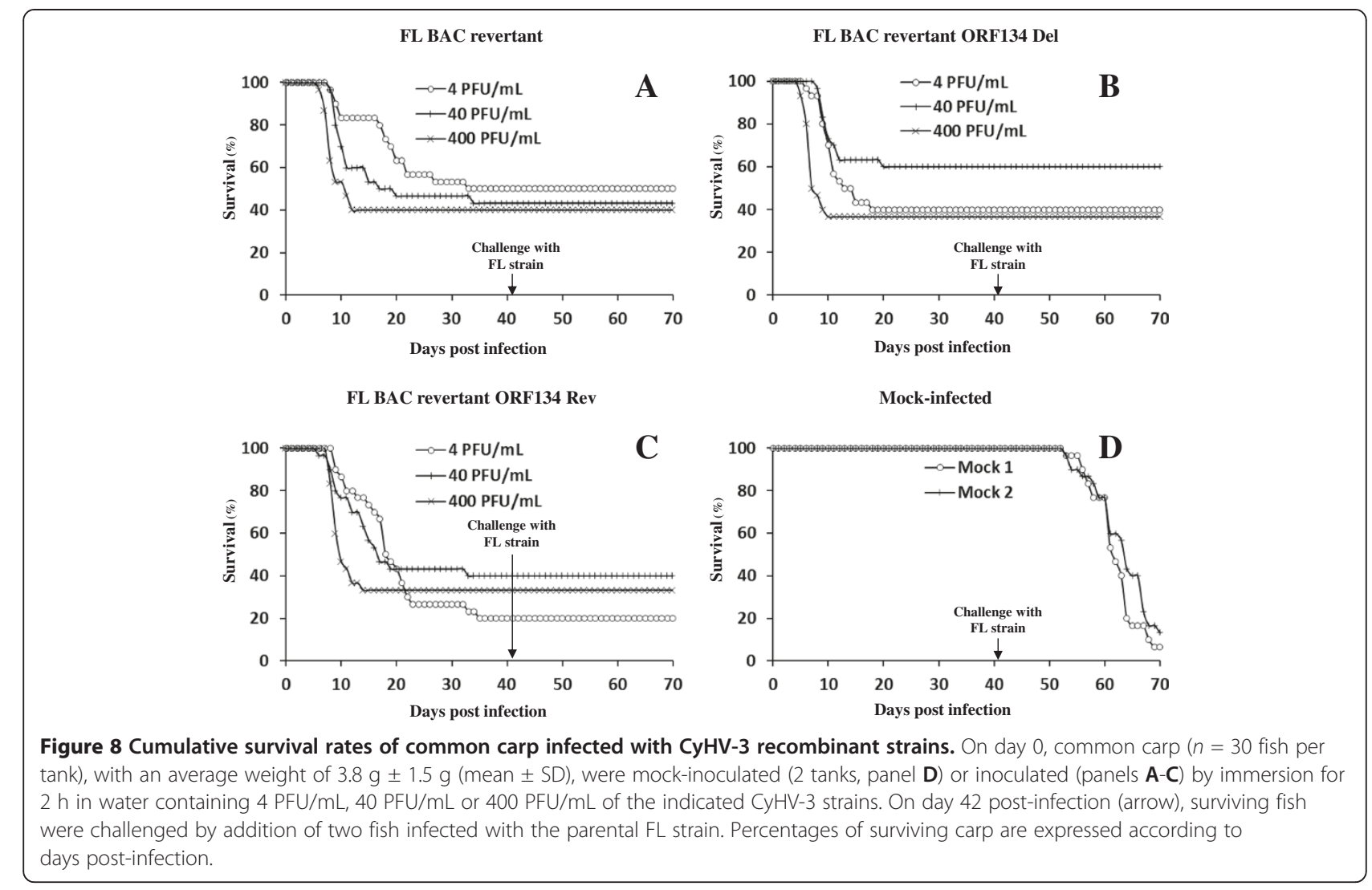

\section{Effect of ORF134 deletion on viral growth in vitro}

In order to investigate the putative effects of the recombination processes on viral growth in vitro, the FL BAC revertant, the FL BAC revertant ORF134 Del and the FL BAC revertant ORF134 Rev were compared using a multi-step growth assay (Figure 7). All viruses tested exhibited similar growth curves $(P \leq 0.05)$, leading to the conclusion that ORF134 deletion does not affect viral growth in vitro (Figure 7 ). This observation is consistent with what has been reported for other vIL-10s [23,25]. Taken together, these results indicate that ORF134 is not essential for CyHV-3 replication in vitro and suggest that ORF134 exerts its biological functions in vivo.

\section{Effect of ORF134 deletion on CyHV-3 pathogenesis}

To investigate the importance of ORF134 in the pathogenesis of CyHV-3 disease, naïve common carp were inoculated by immersion in water containing the FL BAC

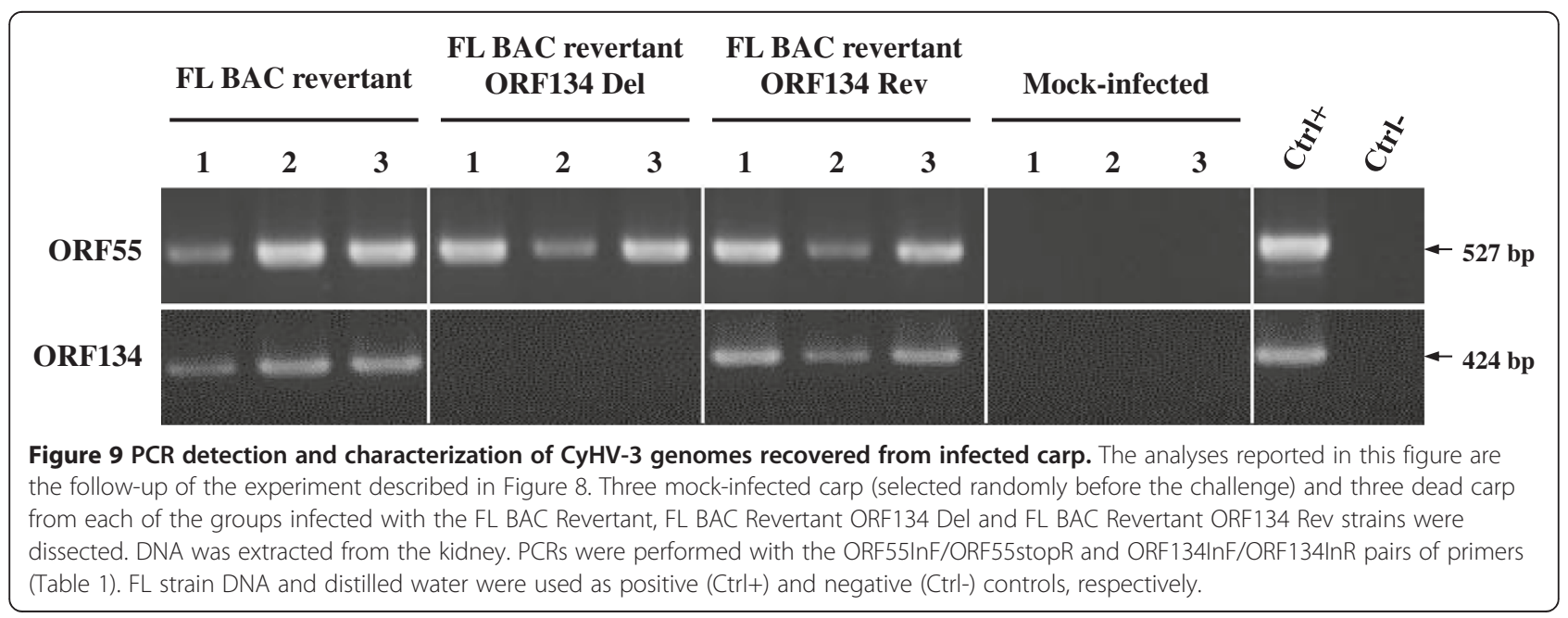


revertant, FL BAC revertant ORF134 Del or FL BAC revertant ORF134 Rev strains (Figure 8). The three strains induced at comparable levels all the clinical signs associated with the disease, including apathy, folding of the dorsal fin, hyperemia, increased mucus secretions, skin lesions, suffocation, erratic swimming, and the loss of equilibrium. The mortality rate and the kinetics of mortality observed for the three strains were not significantly different. At necropsy, similar lesions were observed for the three strains including the discoloration of gill filaments, herpetic skin lesions, and necrotic nephritis. To control that the infection of all groups of fish was performed with the correct viral strain and to exclude any possibility of wild type virus spread among tanks, PCR assays were performed on three randomly selected dead fish from each infected group and three mockinfected fish randomly selected (Figure 9). The PCR results confirmed that each tank was infected with the correct strain and demonstrated the absence of viral spread between tanks. Next, to determine whether the ORF134 deletion affects the adaptive immune response developed by fish that survived primary infection; surviving fish were challenged by co-habitation with fish inoculated with the wild type FL strain (Figure 8). Independently of the viral strain used for the primary infection, none of the challenged fish developed CyHV-3 disease (Figure 8). In contrast, CyHV-3 disease developed in the two tanks that were initially mock-infected. Taken together, the results presented above suggest that ORF134 deletion does not affect CyHV-3 pathogenicity in common carp and the protective immune response developed by surviving fish.

To further test these hypotheses, we investigated the effect of ORF134 deletion on viral load (Figure 10) and on cytokine expression (Figure 11) during CyHV-3 disease. Naïve common carp were inoculated by immersion in water containing the FL BAC revertant, FL BAC revertant ORF134 Del or FL BAC revertant ORF134 Rev strains (Figure 10). At different times after inoculation gill, kidney and spleen were collected from randomly selected fish. Viral loads were analyzed in gill and kidney by real-time TaqMan PCR (Figure 10) while cytokine expression was studied in spleen by RT-qPCR (Figure 11).

Real-time TaqMan PCR results demonstrated that fish infected with the three viral strains had statistically comparable viral loads in the gills and the kidney throughout the course of the experiment (Figure 10). Using the approach described in Figure 9, PCR reactions were performed on randomly selected fish demonstrated that each tank was infected with the correct strain and confirmed the absence of viral spread between tanks (data not shown). Together, these results suggested that ORF134 deletion has no effect on viral load during primary acute infection.
The spleen is one of the organs in which CyHV-3 is the most abundant during the course of acute infection [36]. It is also considered as one of the major lymphoid organ in teleost [44]. In order to study the effect of CyHV-3 ORF134 on the carp immune response, the kinetics of gene expression of the cytokines IFN- $\gamma 2$, TNF $\alpha 1, T N F \alpha 2$, IL- $1 \beta$, IL-6, CXCa and IL-10 were analyzed in spleen from fish infected with FL BAC revertant, FL BAC revertant ORF134 deleted and FL BAC revertant ORF134 Rev strains (Figure 11). Samples were collected over a period of 2 to 8 days post-infection and analyzed by RT-qPCR. The kinetics of expression of studied cytokines showed similar patterns to those observed previously [37]. Taking mock-infected fish as a reference, expression of several cytokines (IFN- $\gamma 2$, IL-1 $\beta$, IL-6, and IL-10) was up-regulated as early as day 3 post-infection. The most pronounced up-regulation was

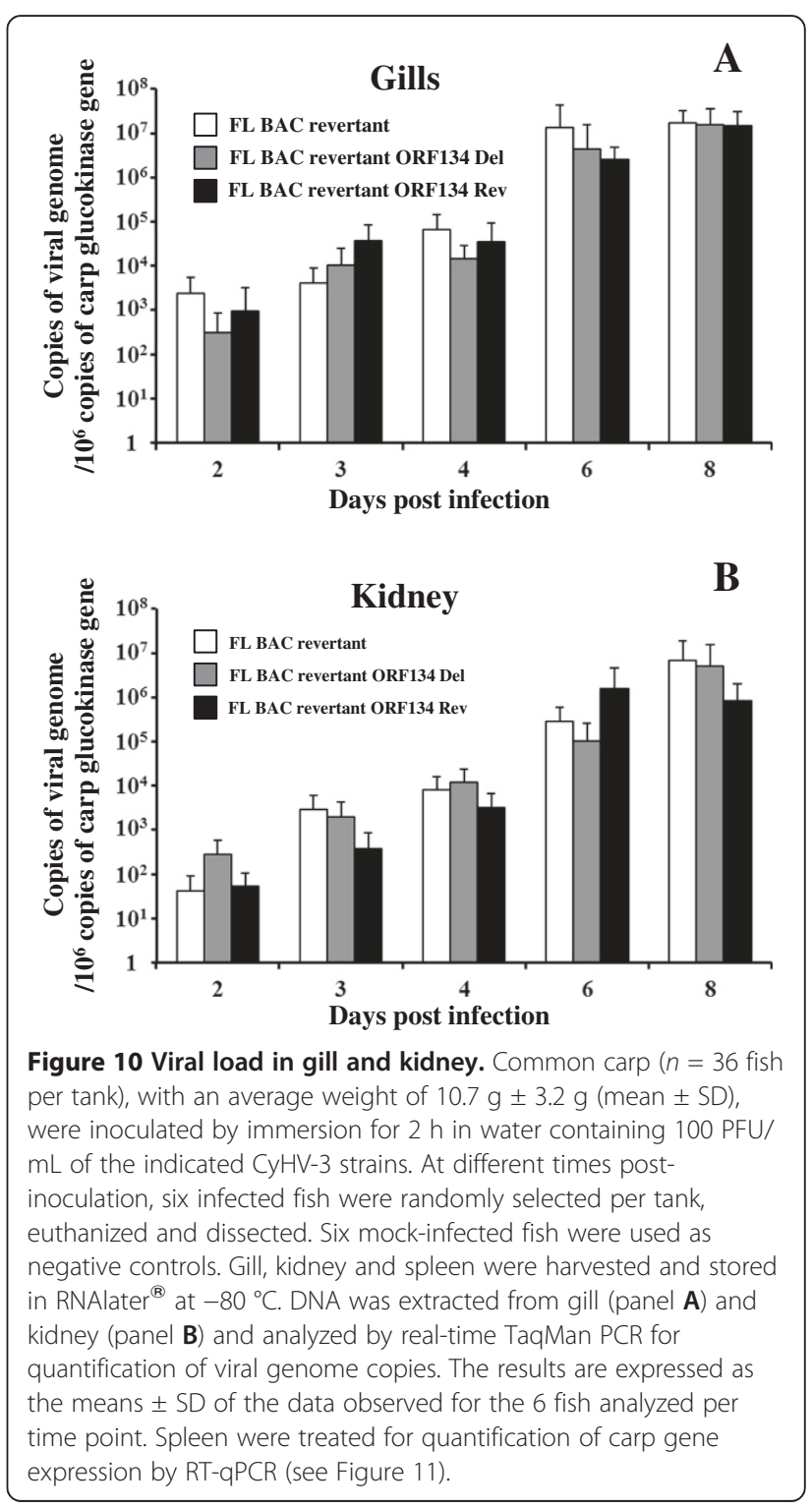




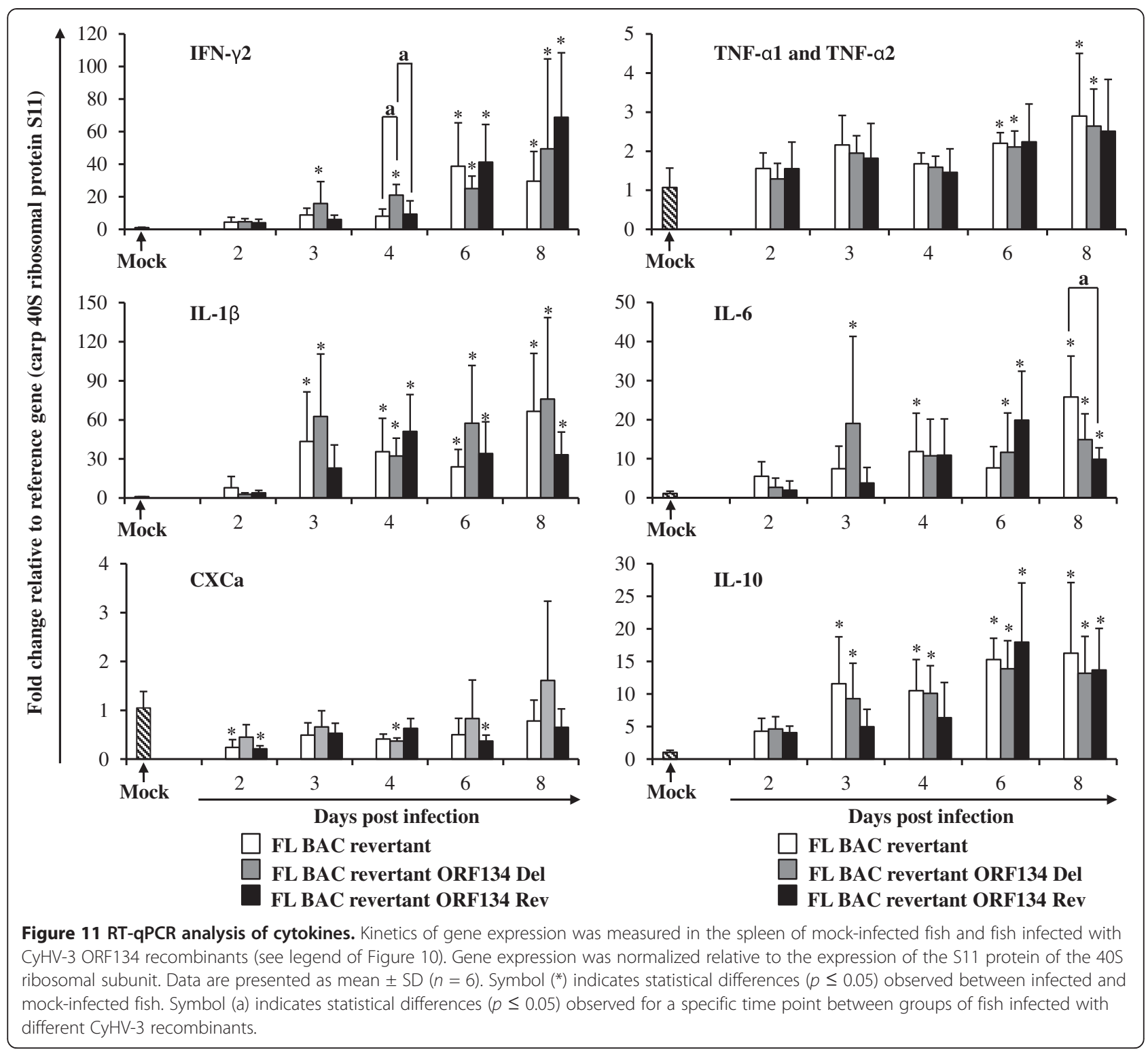

observed for IL-1 $1 \beta$ and IFN- $\gamma 2$. We observed a moderate and late (day 6 and day 8 post-infection) up-regulation of TNF $\alpha 1$ and TNF $\alpha 2$. The expression level of CXCa in infected fish was comparable to mock-infected fish or even down-regulated for some strains at some time points. Importantly, the results presented in Figure 11 demonstrate that there is almost no difference in the expression levels of the cytokines studied between carp infected with three virus strains. The only significant differences observed between virus strains were for IFN- $\gamma 2$ at day 4 postinoculation and for IL-6 at day 8 post-inoculation. The expression level of IFN- $\gamma 2$ at day 4 post-inoculation was significantly higher in fish infected with FL BAC revertant ORF134 deleted as compared to FL BAC revertant and FL BAC revertant ORF134 Rev strains. However, this difference was rather small and was not observed for the other sampling points, suggesting that it could reflect data variation rather than the expression of ORF134 biological activities. Supporting the latter hypothesis, the expression level of IL-6 at day 8 post-inoculation was significantly higher in the FL BAC revertant group as compared to the FL BAC revertant ORF134 Rev group. The absence of cross-contamination between tanks was controlled using the approach described in Figure 9 (data not shown). Together, these results suggested that ORF134 does not significantly affect the carp immune response under the experimental conditions used.

Finally, to investigate further the effect of ORF134 in CyHV-3 pathogenesis, the lesions induced by the FL BAC revertant, FL BAC revertant ORF134 Del and FL 


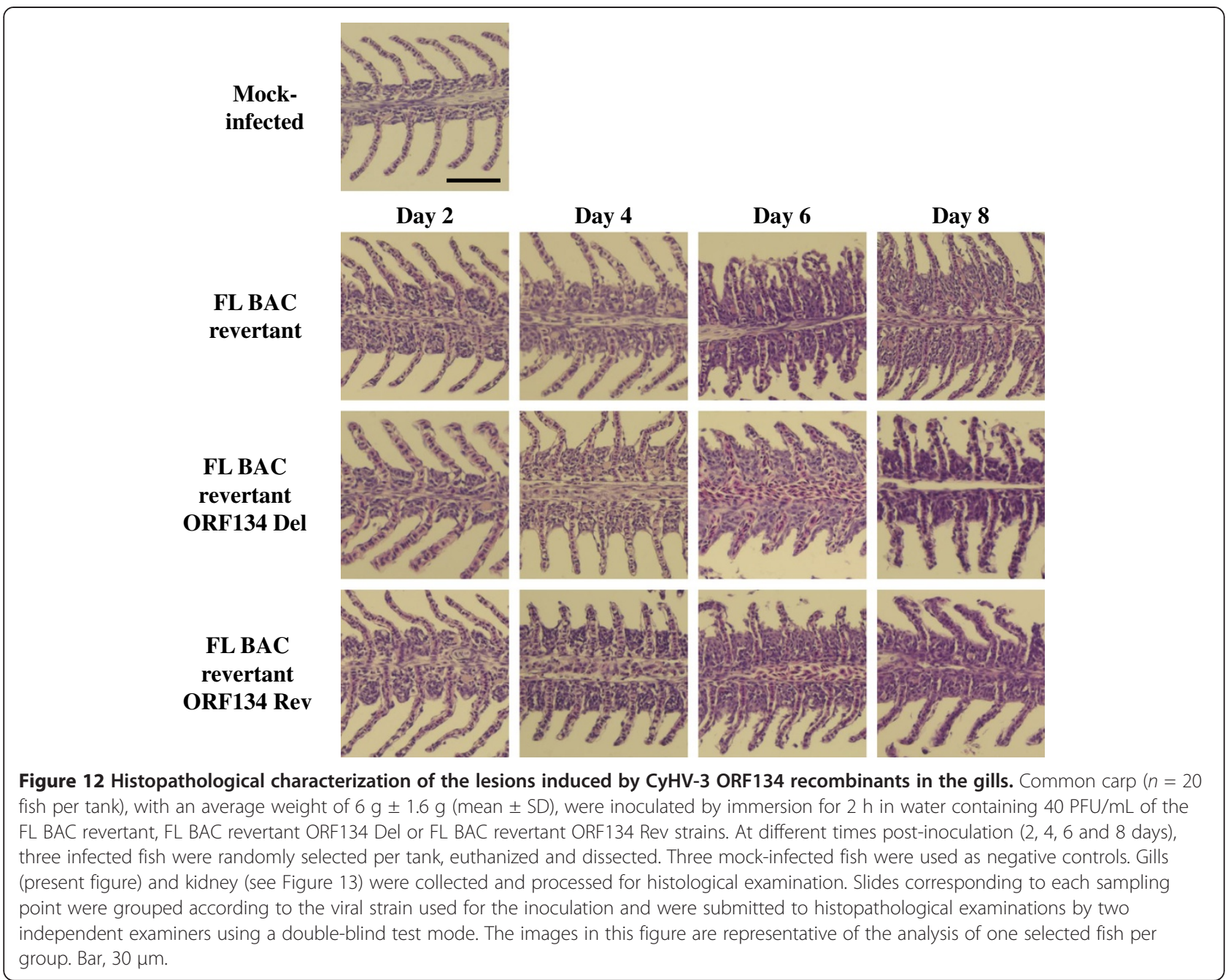

BAC revertant ORF134 Rev strains were compared in the gills and the kidney at various time points after infection (Figures 12 and 13). Histopathological preparations were grouped according to the virus genotype used for the infection and the time point of sampling. The groups of slides were observed by two independent examiners using a double-blind test. The principal histopathological changes were observed in gill filaments. Gills from mock-infected fish exhibited a normal structure. However, a weak lymphocytic hyperplasia was observed for the three mock-infected fish at the basis of the secondary lamellae, leading to their fusion. Few eosinophilic granulocytes were also observed along the primary lamella. As early as 2 days post-infection, both examiners were able to discriminate the three groups of infected fish from the mock-infected group. For all three infected groups, we observed congestion of the secondary lamellae, infiltration of lymphocytes and histiocytes at the basis of secondary lamellae further increasing their fusion. With the exception of one fish from the FL BAC revertant
ORF134 Del group that exhibited weaker histopathological changes (see Figure 12, Day 2), the two other fish from this group expressed changes comparable to those observed in the two other infected groups. The absence of differences between the three viral groups was confirmed at the latter time points. At day 4 post-infection, all fish expressed comparable increased lymphocytic and histocytic infiltrate at the basis of the secondary lamellae. In some fish, an increase of eosinophilic granulocytes was observed (FL BAC revertant: 2 out of 3 fish; FL BAC revertant ORF134 Del: 2 out of 3 fish and FL BAC revertant ORF134 Rev strains 1 out of 3 fish). In comparison to day 2 post-infection, the infiltrate was more pronounced and the congestion was associated with edema of the secondary lamellae. The intensity of the lesions increased comparably in all three groups at latter time-points (Day 6 and Day 8 ). The infiltrate mainly lymphocytic induced the fusion of the lamellae on approximately $2 / 3$ of their length. The respiratory epithelium exhibited hyperplasia and necrosis, associated in few cells with intranuclear inclusion 


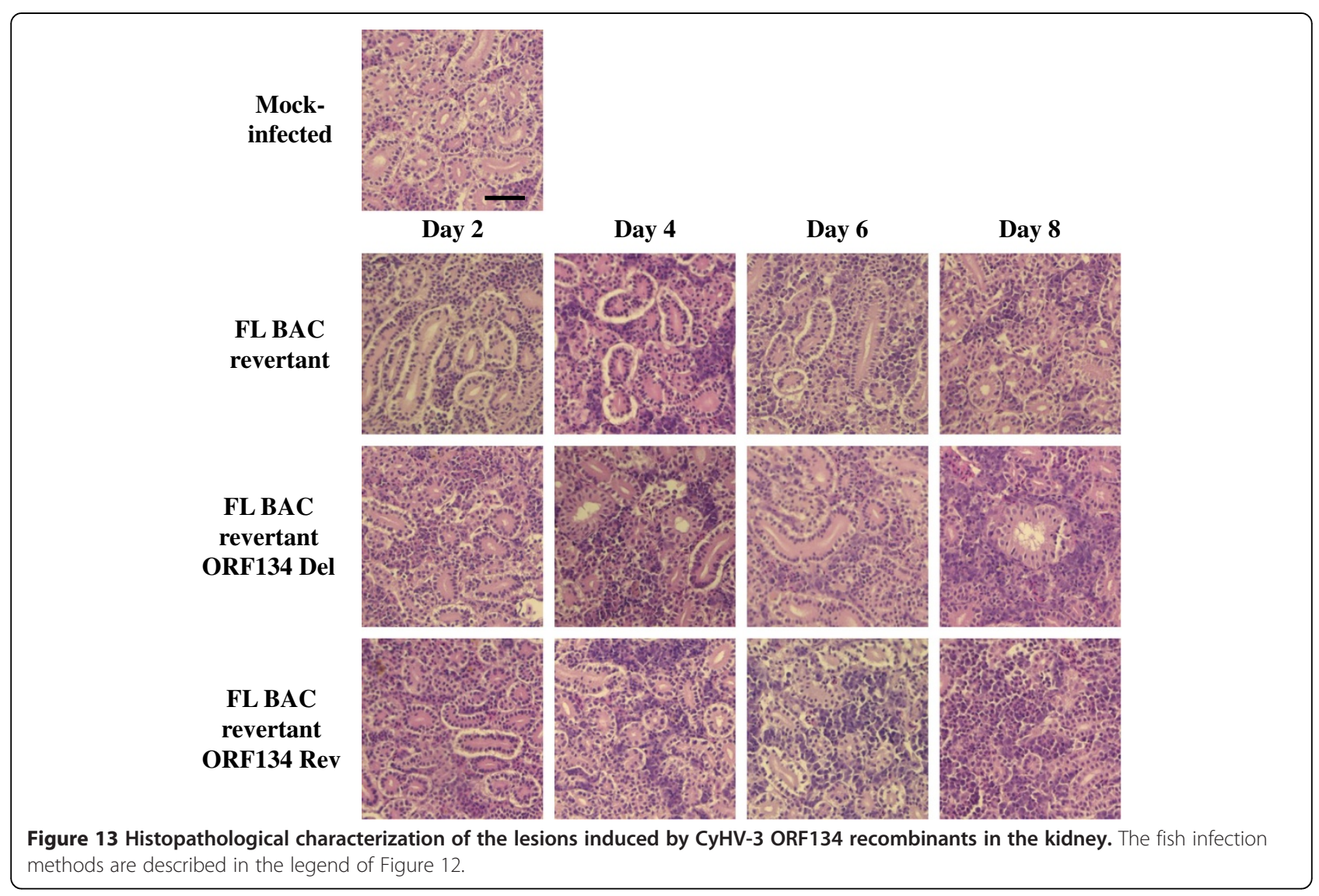

bodies. Compared to day 6 post-infection, the infiltrate observed on day 8 was slightly reduced while the edema and the necrosis were increased. The lesions induced by the three recombinant strains were also compared in the kidney (Figure 13). The lesions observed in this organ were less obvious than in the gills. On day 2 post-infection, infected groups could not be differentiated from the mock-infected one. The diversity and the abundance of hematopoietic cells were normal. However, a slight increase of eosinophilic cells was observed in nearly all groups. Vacuolization of the epithelium was observed in all preparations, and was considered to be a preparation artifact. Starting on day 4 post-infection, both examiners were able to discriminate the three infected groups from the mock-infected one. However, they could not differentiate the three infected groups. Comparable proliferation of the hematopoietic cells, mainly lymphocytic and eosinophilic, was observed in all infected groups. The proliferation increased further on day 6 and 8. Intranuclear inclusion bodies were observed in a few hematopoietic cells on days 6 and 8, and in few epithelial cells on day 8 . The absence of cross-contamination between tanks was controlled using the approach described in Figure 9 (data not shown).

\section{Discussion}

The present study was devoted to CyHV-3 ORF134, which encodes a potential vIL-10. We confirmed that ORF134 is transcribed as a spliced E-L gene (Figure 2). We also demonstrated for the first time that it is one of the most abundant proteins of the CyHV-3 secretome (Table 1) and that ORF134 is essential neither for viral replication in vitro nor for virulence in vivo. The latter conclusion relied on the observations that an ORF134 deleted strain could not be differentiated from its parental and revertant strains based on induced clinical signs and mortality rate (Figure 8), kinetic of viral load in gills and kidney (Figure 10), kinetic of cytokine expression in the spleen (Figure 11) and histological examination of gill and kidney (Figure 12).

As described in the introduction, cellular IL-10 is a pleiotropic immunomodulatory cytokine with both immunostimulatory and immunosuppressive properties [14]. Virally encoded IL-10 homologues have been reported in several members of the Poxviridae family and the Herpesvirales order [19-21]. Numerous molecular and in vitro studies suggest that there has been adaptive evolution of viral IL-10 following capture through positive selection to retain properties most beneficial for 
the virus life cycle. However, very few studies have addressed the role of viral IL-10 in vivo by comparison of a wild type strain and derived deleted and revertant strains. This approach, which is the only one that can test the in vivo biological relevance of a gene, has been performed for only two viruses: rhesus cytomegalovirus (rhesus CMV) and Orf virus (ORFV) [23-25]. For both viruses, deletion of viral IL-10 induced virus attenuation and modulation of the host anti-viral innate immune response.

The results of the present study demonstrate that the IL-10 homologue encoded by CyHV-3 does not affect significantly its virulence in common carp (Figure 8) or the host innate immune response (Figure 11). However, a recent study based on an in vivo artificial model suggested that CyHV-3 ORF134 encodes a functional vIL-10 [26]. As IL-10 is known to induce a transient neutrophilia and monocytosis in addition to $\mathrm{T}$ cell suppression [45], these authors tested the in vivo functionality of CyHV-3 encoded IL-10 by injection of zebrafish embryos with mRNA encoding CyHV-3 ORF134 and analysis by wholemount in situ hybridization (using a pan-leukocyte marker lysozyme at 56 hours post-fertilization before development of $\mathrm{T}$ cells). A slight but statistically significant increase in the number of lysozyme positive cells was observed in embryos injected with CyHV-3 ORF134 mRNA compared to control embryos. The effect observed was inhibited by down regulation of the IL-10 receptor long chain by a specific morpholino. These data suggested that CyHV-3 ORF134 encodes a functional vIL-10. Importantly, the ORF134 sequence used in this study is identical to the sequence encoded by the CyHV-3 strain used in the present study. Various hypotheses could explain the apparent paradox between the functional effect reported by Sunarto et al. and the lack of effect of deleting ORF134 described in the present study [26].

Firstly, it is possible that the slight effect observed by Sunarto et al. using optimal artificial conditions (overexpression of ORF134, no inflammatory stimulation by the viral infection, a rather immature host immune system) has no significant biological relevance during a real viral infection of carp. Secondly, it is possible that the role of ORF134 is strictly restricted to latency and viral reactivation. This hypothesis is inconsistent with the higher level of ORF134 expression observed during acute infection compared to those observed during latency and reactivation [26]. However, experiments are in progress to determine whether ORF134 deletion affects viral load during latency and/or the ability of the virus to reactivate and to be excreted. Thirdly, it may be that ORF134 expression product has a biological activity in zebrafish but not in common carp. This hypothesis is related to the still unknown origin of CyHV-3. Indeed, the rapid emergence of CyHV-3 in the common and koi carp population during the late 90 s and the relatively low polymorphism existing between CyHV-3 isolates suggest that CyHV-3 is the consequence from a recent host-jump from a yet unidentified fish species to common and koi carp. According to this evolutionary scenario, it could be that ORF134 is functional in the CyHV-3 original host species and closely related species but not in the recently colonized common and koi carp species.

In conclusion, the present study addressed for the first time the in vivo role of a vIL-10 encoded by a member of the family Alloherpesviridae. It demonstrates that CyHV-3 ORF134 does not contribute significantly to viral growth in vitro or to virulence in vivo under the conditions tested. However, it is possible that this protein is important under circumstances that were not recapitulated in the present laboratory setting.

\section{Abbreviations}

AngHV-1: Anguilid herpesvirus 1; BAC: Bacterial artificial chromosome; CCB: Cyprinus carpiocarpio brain cell; CHX: Cycloheximide; CyHV-3: Cyprinid herpesvirus-3; Ct: Threshold cycle; DMEM: Dulbecco's modified essential medium; E: Early; EBV: Epstein-Barr virus; EGFP: Enhanced green fluorescent protein; galK: Galactokinase; HCMV: Human cytomegalovirus; IE: Immediate early; IFN: Interferon; IL-10: Interleukin-10; KHV: Koi herpesvirus; L: Late; MOI: Multiplicity of infection; MS: Mass spectrometry; ORF: Open reading frame; ORFV: Orf virus; PBS: Phosphate buffered saline; PAA: Phosphonoacetic acid; PFU: Plaque forming unit; Rhesus CMV: Rhesus cytomegalovirus; RTPCR: Reverse transcription PCR; RT-qPCR: Real-time quantitative PCR; TK: Thymidine kinase; VIL-10: Virally encoded IL-10 homologues.

\section{Competing interests}

The authors declare that they have no competing interests.

\section{Authors' contributions}

PO did most of the experiments. PO, KR, MB, AR, MR, GF, BC and AV contributed to the design of the study. $P O$ and $K R$ drafted the figures. $\mathrm{BL}$ and RW performed proteomic analyses. SC produced recombination cassettes. Statistical analyses were performed by KR. AV conceived the study and drafted the manuscript. All authors read and approved the final manuscript.

\section{Acknowledgments}

$\mathrm{PO}$ is a research fellow of the Chinese Scholarship Council. This work was supported by a grant from the University of Liège and by grants of the "Fonds National Belge de la Recherche Scientifique" (FNRS) (R.FNRS.2165, 2697). KR and AV are members of the BELVIR consortium (IAP, phase VII) granted by the Belgian Science Policy Office (BELSPO) (Belgium).

\section{Author details}

${ }^{1}$ Immunology-Vaccinology (B43b), Department of Infectious and Parasitic Diseases (B43b), Faculty of Veterinary Medicine, University of Liège, Liège B4000, Belgium. ${ }^{2}$ Proteomic and Microbiology, CISMa, University of Mons, Place du parc, 20, Mons B-7000, Belgium. ${ }^{3}$ Delphi Genetics SA, rue Antoine de Saint-Exupéry, 5, Gosselies B-6041, Belgium. ${ }^{4}$ Femalon S.A, Rue du Travail, 16, Grâce-Hollogne B-4460, Belgium.

Received: 15 April 2013 Accepted: 10 June 2013

Published: 16 July 2013

\section{References}

1. Bretzinger A, Fischer-Scherl T, Oumouna M, Hoffmann R, Truyen U: Mass mortalities in Koi carp, Cyprinus carpio, associated with gill and skin disease. Bull Eur Assoc Fish Pathol 1999, 19:182-185.

2. Hedrick R, Gilad O, Yun S, Spangenberg J, Marty G, Nordhausen R, Kebus M, Bercovier $\mathrm{H}$, Eldar A: A herpesvirus associated with mass mortality of 
juvenile and adult koi, a strain of common carp. J Aquat Anim Health 2000, 12:44-57.

3. Hedrick RP: Movement of pathogens with the international trade of live fish: problems and solutions. Rev Sci Tech 1996, 15:523-531.

4. Haenen O, Way K, Bergmann S, Ariel E: The emergence of koi herpesvirus and its significance to European aquaculture. Bull Eur Assoc Fish Pathol 2004, 24:293-307.

5. Michel B, Fournier G, Lieffrig F, Costes B, Vanderplasschen A: Cyprinid herpesvirus 3. Emerg Infect Dis 2010, 16:1835-1843.

6. Aoki T, Hirono I, Kurokawa K, Fukuda H, Nahary R, Eldar A, Davison AJ, Waltzek TB, Bercovier H, Hedrick RP: Genome sequences of three koi herpesvirus isolates representing the expanding distribution of an emerging disease threatening koi and common carp worldwide. J Virol 2007, 81:5058-5065.

7. Davison AJ, Kurobe T, Gatherer D, Cunningham C, Korf I, Fukuda H, Hedrick RP, Waltzek TB: Comparative genomics of carp herpesviruses. J Virol 2013, 87:2908-2922

8. Waltzek TB, Kelley GO, Stone DM, Way K, Hanson L, Fukuda H, Hirono I, Aoki T, Davison AJ, Hedrick RP: Koi herpesvirus represents a third cyprinid herpesvirus (CyHV-3) in the family Herpesviridae. J Gen Virol 2005, 86:1659-1667.

9. Davison AJ, Eberle R, Ehlers B, Hayward GS, McGeoch DJ, Minson AC, Pellett PE, Roizman B, Studdert MJ, Thiry E: The order Herpesvirales. Arch Virol 2009, 154:171-177.

10. McGeoch DJ, Rixon FJ, Davison AJ: Topics in herpesvirus genomics and evolution. Virus Res 2006, 117:90-104

11. Ilouze M, Dishon A, Kahan T, Kotler M: Cyprinid herpes virus-3 (CyHV-3) bears genes of genetically distant large DNA viruses. FEBS Lett 2006, 580:4473-4478.

12. Savan $R$, Igawa $D$, Sakai M: Cloning, characterization and expression analysis of interleukin-10 from the common carp, Cyprinus carpio $\mathrm{L}$. Eur J Biochem 2003, 270:4647-4654

13. Zhang DC, Shao YQ, Huang YQ, Jiang SG: Cloning, characterization and expression analysis of interleukin-10 from the zebrafish (Danio rerion). J Biochem Mol Biol 2005, 38:571-576.

14. Sabat R, Grutz G, Warszawska K, Kirsch S, Witte E, Wolk K, Geginat J: Biology of interleukin-10. Cytokine Growth Factor Rev 2010, 21:331-344.

15. de Waal MR, Abrams J, Bennett B, Figdor CG, de Vries JE: Interleukin 10(IL10) inhibits cytokine synthesis by human monocytes: an autoregulatory role of IL-10 produced by monocytes. J Exp Med 1991, 174:1209-1220.

16. Fiorentino DF, Zlotnik A, Mosmann TR, Howard M, O'Garra A: IL-10 inhibits cytokine production by activated macrophages. J Immunol 1991, 147:3815-3822

17. Moore KW, de Waal MR, Coffman RL, O'Garra A: Interleukin-10 and the interleukin-10 receptor. Annu Rev Immunol 2001, 19:683-765.

18. Couper KN, Blount DG, Riley EM: IL-10: the master regulator of immunity to infection. J Immunol 2008, 180:5771-5777.

19. Slobedman B, Barry PA, Spencer JV, Avdic S, Abendroth A: Virus-encoded homologs of cellular interleukin-10 and their control of host immune function. J Virol 2009, 83:9618-9629.

20. Kotenko SV, Pestka S: Viral IL-10 variants. In Cytokine reference: a compendium of cytokines and other mediators of host defence. Edited by Oppenheim JJ, Feldmann M. New York: Academic Press; 2001.

21. Hughes AL: Origin and evolution of viral interleukin-10 and other DNA virus genes with vertebrate homologues. J Mol Evol 2002, 54:90-101.

22. van Beurden SJ, Forlenza M, Westphal AH, Wiegertjes GF, Haenen OL Engelsma MY: The alloherpesviral counterparts of interleukin 10 in European eel and common carp. Fish Shellfish Immunol 2011, 31:1211-1217.

23. Chang WL, Barry PA: Attenuation of innate immunity by cytomegalovirus IL-10 establishes a long-term deficit of adaptive antiviral immunity. ProcNat/AcadSci USA 2010, 107:22647-22652

24. Eberhardt MK, Chang WL, Logsdon NJ, Yue Y, Walter MR, Barry PA: Host immune responses to a viral immune modulating protein: immunogenicity of viral interleukin-10 in rhesus cytomegalovirusinfected rhesus macaques. PLoS One 2012, 7:e37931.

25. Fleming SB, Anderson IE, Thomson J, Deane DL, Mclnnes CJ, McCaughan CA, Mercer AA, Haig DM: Infection with recombinant orf viruses demonstrates that the viral interleukin-10 is a virulence factor. J Gen Virol 2007, 88:1922-1927.

26. Sunarto A, Liongue C, McColl KA, Adams MM, Bulach D, Crane MSJ, Schat KA, Slobedman B, Barnes AC, Ward AC, Walker PJ: Koi herpesvirus encodes and expresses a functional interleukin-10. J Virol 2012, 86:11512-11520.
27. Costes B, Fournier G, Michel B, Delforge C, Raj VS, Dewals B, Gillet L, Drion P, Body A, Schynts F, Lieffrig F, Vanderplasschen A: Cloning of the koi herpesvirus genome as an infectious bacterial artificial chromosome demonstrates that disruption of the thymidine kinase locus induces partial attenuation in Cyprinus carpio koi. J Virol 2008, 82:4955-4964.

28. Markine-Goriaynoff N, Gillet L, Karlsen OA, Haarr L, Minner F, Pastoret P-P, Fukuda M, Vanderplasschen A: The core $2 \beta-1,6-N$-acetylglucosaminyltransferase-M encoded by bovine herpesvirus 4 is not essential for virus replication despite contributing to post-translational modifications of structural proteins. J Gen Virol 2004, 85:355-367

29. Houze M, Dishon A, Kotler M: Coordinated and sequential transcription of the cyprinid herpesvirus-3 annotated genes. Virus Res 2012, 169:98-106.

30. Ilouze M, Dishon A, Kotler M: Down-regulation of the cyprinid herpesvirus-3 annotated genes in cultured cells maintained at restrictive high temperature. Virus Res 2012, 169:289-295.

31. Michel B, Leroy B, Stalin Raj V, Lieffrig F, Mast J, Wattiez R, Vanderplasschen $A F$, Costes $B$ : The genome of cyprinid herpesvirus 3 encodes 40 proteins incorporated in mature virions. J Gen Virol 2010, 91:452-462.

32. Mastroleo F, Leroy B, Van Houdt RS, Heeren C, Mergeay M, Hendrickx L, Wattiez R: Shotgun proteome analysis of Rhodospirillum rubrum $\mathrm{S} 1 \mathrm{H}$ : integrating data from gel-free and gel-based peptides fractionation methods. J Proteome Res 2009, 8:2530-2541.

33. Ishihama Y, Oda Y, Tabata T, Sato T, Nagasu T, Rappsilber J, Mann M: Exponentially modified protein abundance index (emPAl) for estimation of absolute protein amount in proteomics by the number of sequenced peptides per protein. Mol Cell Proteomics 2005, 4:1265-1272.

34. Warming S, Costantino N, Court DL, Jenkins NA, Copeland NG: Simple and highly efficient BAC recombineering using galK selection. Nucleic Acids Res 2005, 33:e36.

35. Costes B, Raj VS, Michel B, Fournier G, Thirion M, Gillet L, Mast J, Lieffrig F, Bremont $M$, Vanderplasschen $A$ : The major portal of entry of koi herpesvirus in Cyprinus carpio is the skin. J Virol 2009, 83:2819-2830.

36. Gilad O, Yun S, Zagmutt-Vergara FJ, Leutenegger CM, Bercovier H, Hedrick RP: Concentrations of a Koi herpesvirus (KHV) in tissues of experimentally infected Cyprinus carpio koi as assessed by real-time TaqMan PCR. Dis Aquat Organ 2004, 60:179-187.

37. Rakus KL, Irnazarow I, Adamek M, Palmeira L, Kawana Y, Hirono I, Kondo H, Matras M, Steinhagen D, Flasz B, Brogden G, Vanderplasschen A, Aoki T: Gene expression analysis of common carp (Cyprinus carpio L.) lines during Cyprinid herpesvirus 3 infection yields insights into differential immune responses. Dev Comp Immunol 2012, 37:65-76.

38. Livak KJ, Schmittgen TD: Analysis of relative gene expression data using realtime quantitative PCR and the $2^{-\Delta \Delta C T}$ Method. Methods 2001, 25:402-408.

39. Dewals B, Boudry C, Gillet L, Markine-Goriaynoff N, De Leval L, Haig D, Vanderplasschen A: Cloning of the genome of Alcelaphine herpesvirus 1 as an infectious and pathogenic bacterial artificial chromosome. J Gen Virol 2006, 87:509-517.

40. Fleming SB, McCaughan CA, Andrews AE, Nash AD, Mercer AA: A homolog of interleukin-10 is encoded by the poxvirus orf virus. J Virol 1997, 71:4857-4861.

41. Lockridge KM, Zhou SS, Kravitz RH, Johnson JL, Sawai ET, Blewett EL, Barry PA: Primate cytomegaloviruses encode and express an IL-10-like protein. Virology 2000, 268:272-280.

42. Drummer HE, Studdert MJ, Crabb BS: Equine herpesvirus-4 glycoprotein G is secreted as a disulphide-linked homodimer and is present as two homodimeric species in the virion. J Gen Virol 1998, 79:1205-1213.

43. Costes B, Ruiz-Arguello MB, Bryant NA, Alcami A, Vanderplasschen A: Both soluble and membrane-anchored forms of Felid herpesvirus 1 glycoprotein $\mathrm{G}$ function as a broad-spectrum chemokine-binding protein. J Gen Virol 2005, 86:3209-3214.

44. Rombout JH, Huttenhuis HB, Picchietti S, Scapigliati G: Phylogeny and ontogeny of fish leucocytes. Fish Shellfish Immunol 2005, 19:441-455.

45. Chernoff AE, Granowitz EV, Shapiro L, Vannier E, Lonnemann G, Angel JB, Kennedy JS, Rabson AR, Wolff SM, Dinarello CA: A randomized, controlled trial of IL-10 in humans. Inhibition of inflammatory cytokine production and immune responses. J Immunol 1995, 154:5492-5499.

\section{doi:10.1186/1297-9716-44-53}

Cite this article as: Ouyang et al:: The IL-10 homologue encoded by cyprinid herpesvirus 3 is essential neither for viral replication in vitro nor for virulence in vivo. Veterinary Research 2013 44:53. 